\title{
Impact of Shelterbelt and Peatland Barriers on Agricultural Landscape Groundwater: Carbon and Nitrogen Compounds Removal Efficiency
}

\author{
Marek Szczepański *(D), Lech W. Szajdak and Teresa Meysner \\ Institute for Agricultural and Forest Environment, Polish Academy of Sciences, Bukowska 19, 60-809 Poznań, \\ Poland; lech.szajdak@isrl.poznan.pl (L.W.S.); teresa.meysner@isrl.poznan.pl (T.M.) \\ * Correspondence: marek.szczepanski@isrl.poznan.pl; Tel.: +48-61-8475-601
}

check for updates

Citation: Szczepański, M.; Szajdak, L.W.; Meysner, T. Impact of Shelterbelt and Peatland Barriers on Agricultural Landscape

Groundwater: Carbon and Nitrogen Compounds Removal Efficiency. Agronomy 2021, 11, 1972. https:// doi.org/10.3390/agronomy11101972

Academic Editor: Emily A.

Poppenborg Martin

Received: 24 June 2021

Accepted: 28 September 2021

Published: 30 September 2021

Publisher's Note: MDPI stays neutral with regard to jurisdictional claims in published maps and institutional affiliations.

Copyright: (c) 2021 by the authors. Licensee MDPI, Basel, Switzerland. This article is an open access article distributed under the terms and conditions of the Creative Commons Attribution (CC BY) license (https:// creativecommons.org/licenses/by/ $4.0 /)$.

\begin{abstract}
In the context of declining water quality, the threat of nonpoint source pollution (NSP) to aquatic habitats and species is a well-recognized phenomenon. The recognition of NSP continues to grow as legal regulatory practices as well as public and scientific awareness of this source of pollution increase. Agricultural runoff from farms and fields often contains various contaminants such as pesticides, fertilizers, pathogens, sediments, salts, trace metals, and substances that contribute to changes in biological oxygen demand. Farmers and growers releasing agricultural runoff are increasingly required to implement water-quality regulations and management practices to reduce NSP. Constructed or restored shelterbelts and natural peatlands can be two of the many best management practices farmers can use to address this problem. We compared the barrier efficiency of the agricultural landscape elements, i.e., a shelterbelt of various plant compositions and a peatland, to control the spread of NSP in groundwater between ecosystems. In agricultural areas with high water tables, biogeochemical barriers in the form of shelterbelts and peatlands can remove or retain many groundwater pollutants from agricultural runoff with careful planning and management.
\end{abstract}

Keywords: biogeochemical barriers; shelterbelts; peatlands; nonpoint source pollution; forms of nitrogen and organic carbon; autonomous and heteronymous geochemical landscapes

\section{Introduction}

Nonpoint source pollution (NSP) is a global problem affecting the safety of our drinking water supply, aquatic habitats and groundwater. Pollutants originating from agricultural runoff include a group of inorganic compounds of known and unknown structure, e.g., heavy metals, nitrates, nitrites, phosphates, cyanides, fluorides, sulfates and sulfide ions. The wide group of organic compounds includes organic nitrogenous compounds (amino acids, proteins, peptides, amines, alkaloids, antibiotics, creatine and creatinine), carbohydrates (reducing sugars, starch, soluble carbohydrates, cellulose, holocellulose, alfa cellulose, hemicellulose), vitamins, crude fiber, fatty acids and lipids, flavonoids and related compounds (lignin, phenolic compounds including phenolic acids), plant pigments (including chlorophyll and carotenoids), sterols, pesticides (including herbicides, carbamates, polychlorinated biphenyls), detergents, anionic surfactants, humics and resistant residues as well as suspended matter consisting of plant and animal origins [1,2]. Many physical, chemical, biochemical and biological processes, pathways and mechanisms control the dispersion of these chemicals in soils and waters, and finally, all these processes depend on the organic matter content and especially on humic substances [3-6]. All of these chemicals can be leached to the groundwater in the form of total dissolved carbon and dissolved organic carbon.

Constructed shelterbelts and peatlands have become popular best management practices of fields in agricultural plain regions for the treatment of nitrate contamination in groundwater resources. Almost all chemical forms of high concentration nitrogen stimulate 
the eutrophication process and increase the biological productivity of water, being a limiting nutrient responsible for dead zones in estuaries and oceans that may cause hypoxia, eutrophication, harmful algal blooms and habitat deterioration in rivers and lakes [7-10]. There is a possibility of using dissolved organic $\mathrm{N}$, whose content might be $85 \%$, by the water ecosystem, including bacterio-plankton, cyano-bacteria, and phytoplankton [11]. Moreover, nitrates and nitrites in drinking water have been implicated in the potential for causing methemoglobinemia in infants, bladder, ovarian, stomach and liver human cancers, and also in livestock and pets diseases [12-15].

The successes in reducing point source pollution (PSP) in the natural environment caused interest in a greater focus on the evaluation and regulation of NSP. Thus, control of NSP concerns data retrieval resulting from rainfall-runoff and other diverse water transport processes, responsible for pollution mobility. Modeling of NSP transport serves as a guide for understanding and quantifying the various soil, vegetation, and climatic elements responsible for water quality control. The phenomena of chemical, biochemical and biological material, transported from rainfall-runoff to receiving waters consist of two broad areas of research: (i) conversion in the form and amount of material presented at the land surface and (ii) the transfer and transport of material from the land surface into water moving across or throughout the land, and ultimately to receiving waters [16-19].

Shelterbelts and peatlands in the agricultural landscape fulfill significant positive functions, as geochemical barriers, by reducing soil erosion from wind and protecting plants from wind-related damage [20,21]. Moreover, they improve the microclimate for agricultural production and are able to counteract or minimize the effect of extreme climatic or weather phenomena (particularly low and high temperatures) [22].

One of the most important functions of shelterbelts and peatlands in the agricultural landscape is greater water retention in their soil organic matter layer than in adjoining cultivated fields [23]. Moreover, plant cover increases infiltration rates by slowing runoff, which is of particular importance, against water eutrophication with a high level of fertilization in cultivated fields. Therefore, those barriers limit the spread of chemical compounds in the agricultural landscape between ecosystems, control matter cycling and protect an accumulation of toxic chemicals, and threats [24,25]. However, shelterbelt and peatland efficiency are dependent on water flux intensity, soil permeability, meteorological and weather condition changes as well as the type and quantity of organic matter accumulated under the canopy [26]. A better understanding of the impact of low moor peatlands on the decrease in the quantities of chemical compounds in groundwater should increase our ability to predict the improvement of the quality of groundwater.

The agricultural community requires cost-effective and practical options to attenuate NSP. Natural barriers such as peatlands, shelterbelts, stretches of meadows, grasslands, hedges and riparian vegetation strips are an appealing option because they are effective contaminant removal systems that are relatively inexpensive to develop and maintain [27,28]. Additional ecological services provided by natural barriers in the form of tree plantations include wildlife habitat and biodiversity, hydrologic buffering of surface waters, groundwater recharge zones and aesthetic value. Shelterbelts and peatland systems sequester eroded carbon and endogenous carbon, demonstrating that they have potential as a climate-change mitigation strategy for agriculture [29].

In the case of low concentrations of pollutions from agricultural sources, an effective treatment option for conventional wastewater treatment is to use primary sedimentation followed by secondary biological treatment using high-rate biological processes. However, high energy costs, technology requirements, and frequent maintenance problems render it ineffective for use in most developing countries [30,31]. Thus, the most important methods from the point of ecological engineering are that the biogeochemical barriers: peatlands, shelterbelts, stretches of meadows, grasslands, hedges and riparian vegetation strips exert controlling effects on groundwater pollution. 
The Council of Europe Committee of Ministers in Recommendation No. R(94)6 of the Committee of Ministers to the Member States for Sustainable Development and use of the Countryside with the Particular Focus on the Safeguarding of Wildlife and Landscapes [32] proposed the reduction in pollution concentration in natural habitats through the creation of shelterbelts, buffer zones, windbreaks, natural meadows, and ponds.

The main goal of this study was to estimate the efficiency of peatlands and shelterbelts on changes in the content of various compounds (in particular nitrogen and carbon) in groundwater passing through these agricultural elements, in order to understand their role as functioning biogeochemical barriers. Moreover, the conclusions from the research should recommend which of these agricultural landscape barriers is the most effective in the limitation of NSP to groundwater.

\section{Materials and Methods}

\subsection{Study Area}

The research was carried out at the Gen. Dezydery Chłapowski Landscape Park in Turew (40 km southwest of Poznań, Poland, $52^{\circ} 03^{\prime} 31^{\prime \prime} \mathrm{N}, 16^{\circ} 49^{\prime} 40^{\prime \prime} \mathrm{E}, 85 \mathrm{~m}$ a.s.l.) (Figure 1A). The landscape park (17,000 ha) constitutes protected areas of a long-term study on agricultural landscape ecology [23,24,33-35]. Thus, control of NSP concerns data retrieval resulting from rainfall-runoff. The experimental area is warm in temperature and has a central-eastern European climate, with $575 \mathrm{~mm}$ in precipitation and a mean annual temperature of $8.0^{\circ} \mathrm{C}$. The length of the growing season, with air temperatures above $5{ }^{\circ} \mathrm{C}$, has 225 days on average, beginning in the middle of March till the end of October and is conducive to vegetation.

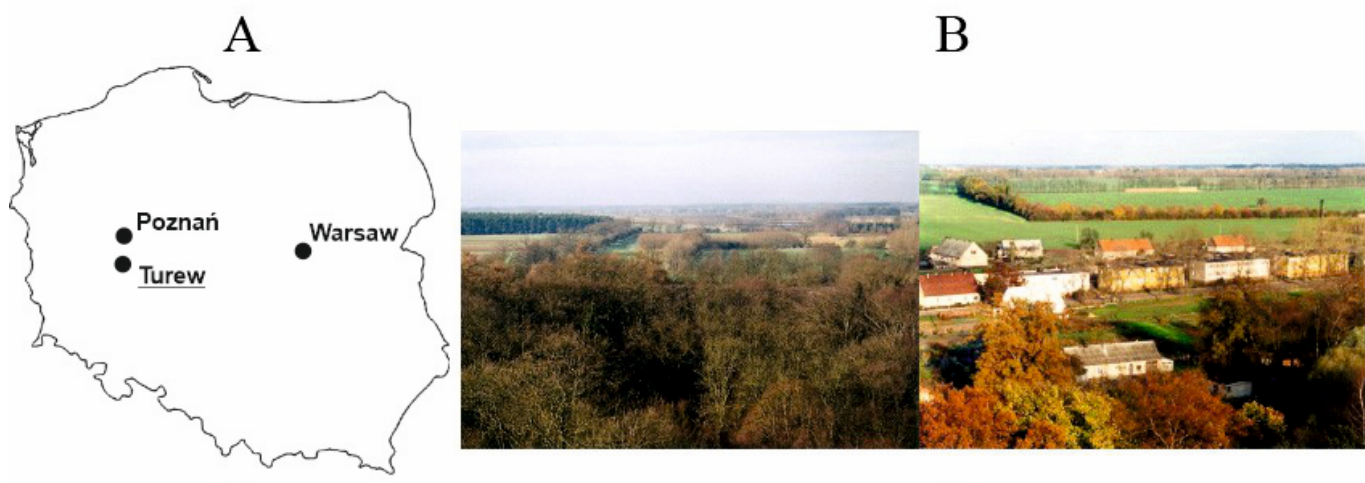

$\mathrm{C}$

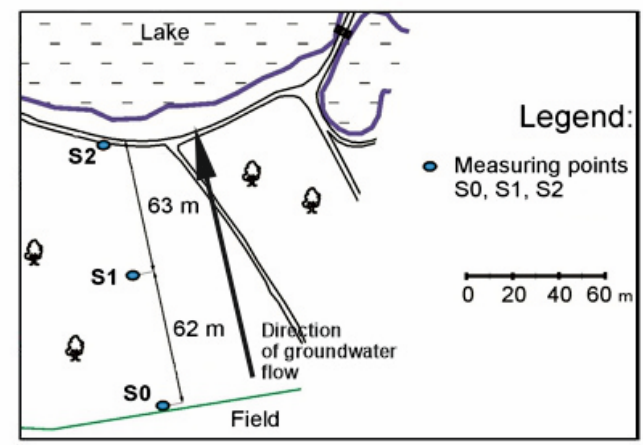

D

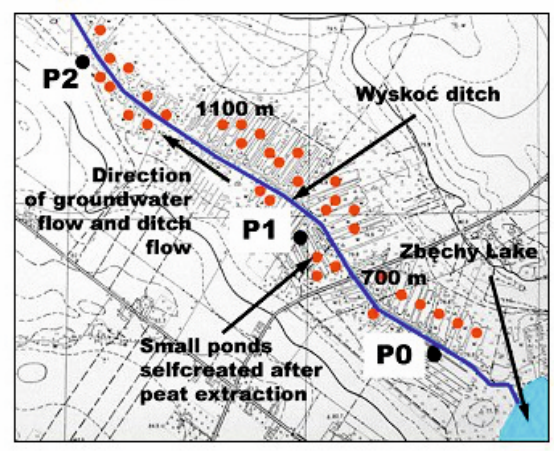

Figure 1. (A): Schematic map of Poland and the location of Turew Village; (B): the landscape of Turew and the system of shelterbelts; (C): map of $125 \mathrm{~m}$ long shelterbelt in Turew Park, (D): scheme of $1800 \mathrm{~m}$ investigated peatland. 
The study area characterizes various kinds of afforestation: Pinus sylvestris L. (65.5\% of the total afforested area), Quercus petraea (Matt.) Liebl. and Q. robur L. (14.5\%), Robinia pseudoacacia L. (5\%), Betula pendula Roth (4.3\%), and others, totaling 24 species. The most advantageous component of the discussed rural landscape shows a system of shelterbelts (rows or clumps of trees) with characteristic features. It was created in the 19th century by Napoleon's general Dezydery Chłapowski, is unique and is in the form of a network (Figure 1B). The total area of all shelterbelts is equal to 560 ha with false acacias, oaks, maples, lindens, larch, and poplars in domination [20].

\subsubsection{Shelterbelt}

Soil samples were taken from three sites (S0, S1, S2) in the $125 \mathrm{~m}$-wide shelterbelt located in the Turew Palace Park (Figure 1C). The shelterbelt is situated between arable land on more high topographic positions and the border of the lake on lower positions. This area is populated by various tree species with maple, ash, beech and hawthorn dominating as well as elderberry likewise in the understory, with a companion crop of young maple, ash and hawthorn. The shelterbelt is located on two different soils: mineral and mineral-organic [36,37] (Table 1).

Table 1. Shelterbelt places and some properties of soils.

\begin{tabular}{ccc}
\hline Place of Sampling & $\begin{array}{c}\text { Botanical Composition of Vegetation Cover of } \\
\text { Investigated Places }\end{array}$ & Mype of Soil \\
\hline $\begin{array}{c}\text { S0-in the boundary } \\
\text { between field and } \\
\text { afforestation }\end{array}$ & $\begin{array}{c}\text { Acer platanoides L., Alliaria petiolate } \text { (M. Bieb.) Cavara and Grande, } \\
\text { Chelidonium majus L., Crataegus monogyna Jacq., Fraxinus excelsior } \\
\text { L., Quercus robur L., Robiniapseudoacacia L., Sambucus nigra L., } \\
\text { Stachys sylvatica L., Ulmuslaevis Pall., Viola odorata L. }\end{array}$ & $\begin{array}{c}\text { Division-autogenic soils, order-brown } \\
\text { forest soils, type-hapludalfs, } \\
\text { subtype-glossudalfs }\end{array}$ \\
\hline $\begin{array}{c}\text { S1-62 m from } \\
\text { the edge }\end{array}$ & $\begin{array}{c}\text { A. platanoides, Carpinus betulus L., Fagus sylvatica L., F. excelsior, } \\
\text { Hedera helix L., Q. robur, S. nigra }\end{array}$ & $\begin{array}{c}\text { Division-autogenic soils, order-brown } \\
\text { forest soils, type-hapludalfs, } \\
\text { subtype-ochraquals }\end{array}$ \\
\hline $\begin{array}{c}\text { S2-125 m from } \\
\text { the edge }\end{array}$ & $\begin{array}{c}\text { A. Mlatanoides, Aegopodium podagraria L., Chaerophyllumaromaticum } \\
\text { L., Ch. temulum, C. monogyna, F. excelsior, Galium aparine L., } \\
\text { Geumurbanum L., H. helix, Ranunculus lanuginosus L., S. nigra, } \\
\text { S. sylvatica, U. laevis, V. odorata }\end{array}$ & $\begin{array}{c}\text { order-post-bog soils, type-mucky soils, } \\
\text { subtype-muckous }\end{array}$ \\
\hline
\end{tabular}

\subsubsection{Transect of Peatland}

The second research site was a transect of peatland $1800 \mathrm{~m}$ long. The investigated three chosen points marked as P0, P1 and P2 were situated along the Wyskoć Ditch (Figure 1D). Between P0 point and Zbęchy Lake there is located approximately $300 \mathrm{~m}$-long arable land. Soil samples were taken from the marked points with increasing distance from the Zbęchy Lake. Peat-moorsh soils were classified according to Polish Hydrogenic Soil Classification [36] and Word Reference Base Soil Resources [37] (Table 2). 
Table 2. Plants associations of investigated peatland and some properties of peat-moorsh soils.

\begin{tabular}{|c|c|c|c|c|}
\hline $\begin{array}{l}\text { Place of } \\
\text { Sam- } \\
\text { pling }\end{array}$ & $\begin{array}{l}\text { Botanical Composition of Vegetation Cover of } \\
\text { Investigated Places }\end{array}$ & $\begin{array}{l}\text { Type of Peat-Moorsh Soils Based } \\
\text { on Macrofossil Analysis }\end{array}$ & $\begin{array}{c}\text { Stage of Soil } \\
\text { Moorshifica- } \\
\text { tion, Degree of } \\
\text { Decomposition }\end{array}$ & $\begin{array}{c}\text { Type of } \\
\text { Moorsh } \\
\text { Forma- } \\
\text { tion }\end{array}$ \\
\hline P0 & $\begin{array}{l}\text { Achillea millefolium L., Acorus calamus L., Alnus } \\
\text { glutinosa (L.) Gaertn., Bidens frondosa L., } \\
\text { Carexacutiformis L., Cerastiumholosteoides L., } \\
\text { Cirsium arvense (L.) Scop., Conyza canadensis (L.) } \\
\text { Cronquist, Epilobium hirsutum L., Galiummollugo } \\
\text { L., G. palustre L., G. uliginosum L., Glechoma } \\
\text { hederacea L., Holcus lanatus L., Iris pseudacorus L., } \\
\text { Lathyrus palustris L., Lemna minor L., Lycopus } \\
\text { europaeus L., Lythrumsalicaria L., Matricaria } \\
\text { maritima (L.) W. D. J. Koch, Mentha aquatica L., } \\
\text { Phalaris arundinacea L., Phleum pratense L., } \\
\text { Phragmites australis (Cav.) Trin. ex Steud, Plantago } \\
\text { lanceolata L., P. major L., Polygonum amphibium (L.) } \\
\text { Delarbre, Potentilla reptans L., Ranunculus repens } \\
\text { L., Rumex crispus L., Sonchus asper (L.) Hill., } \\
\text { Stachys palustris L., Taraxacum officinale F.H. Wigg., } \\
\text { Trifolium hybridum L., T. repens L., Urtica dioica L. }\end{array}$ & $\begin{array}{l}\text { Wooden-sedge moorsh soil with } \\
\text { peat, light degree of moorsh } \\
\text { process MtI, deep soil developed } \\
\text { with low Carex-Phragmiteti } \\
\text { strongly decomposed (sapric) peat, } \\
10 \text { YR } 2 / 1 \text { black, amorfic-fibrus } \\
\text { structure. The upper peat horizon } \\
\text { has thin } 1-2 \text { mm mineral layers. } \\
\text { Peaty muck horizon with } \\
\text { subangular blocky structure with } \\
\text { low fiber content. Moorsh horizon } \\
\text { Mt 0-10 cm depth. Polish } \\
\text { Hydrogenic Soil Classification [36]: } \\
\text { MtIcc. World Reference Base [37] } \\
\text { soil notation: Sapri-Eutric } \\
\text { Histosols. }\end{array}$ & $\begin{array}{c}\text { MtIcc } \\
0-20 \mathrm{~cm}, \\
\text { R3 }\end{array}$ & $\mathrm{Z}_{1}$ \\
\hline $\mathrm{P} 1$ & $\begin{array}{l}\text { Achillea millefolium, Agrostis canina L., } \\
\text { Arrhenatherum elatior (L.) P. Beauv. ex J. and C. } \\
\text { Presl, Carexacutiformis, C. acuta L., } \\
\text { Ceratophyllumdemersum L., Cirsium arvense, C. } \\
\text { oleraceum (L.) Scop., Deschampsiacaespitosa (L.) P.B., } \\
\text { Epilobium hirsutum L., Galiummollugo, Glechoma } \\
\text { hederacea, Heracleum sphondylum L., Holcus lanatus, } \\
\text { Hydrocharismorsus- ranae L., Lemnatrisulca L., } \\
\text { Leucanthemum vulgare Lam., Lolium multiflorum } \\
\text { Lam., Lysimachia vulgaris L., Lythrumsalicaria, } \\
\text { Phragmites australis, Plantago lanceolata, P. major, } \\
\text { Ranunculus repens, Rumex acetosa L., R. crispus, R. } \\
\text { hydrolapathum Huds., Salix alba L., S. cinerea L., } \\
\text { Serratula tinctoria L., Solanum dulcamara L., } \\
\text { Taraxacum officinale, Trifolium pratense L., T. repens, } \\
\text { Typha angustifolia L., Urtica dioica }\end{array}$ & $\begin{array}{l}\text { Alder, moorsh soil with peat, } \\
\text { medium degree of moorsh process } \\
\text { MtII, deep soil developed with low } \\
\text { strongly decomposed (sapric) } \\
\text { wood peat, } 10 \text { YR } 2 / 1 \text { black, } \\
\text { angular blocky structure. Humic } \\
\text { muck horizon with subangular } \\
\text { blocky microstructure. Very } \\
\text { well-developed M1 moorsh sod } \\
\text { subhorizon and subangular blocky } \\
\text { M2 muck under subhorizon. } \\
\text { Moorsh horizon Mt 0-20 cm depth. } \\
\text { Polish Hydrogenic Soil } \\
\text { Classification [36]: MtIIcc. World } \\
\text { Reference Base [37] soil notation: } \\
\text { Sapri-Eutric Histosols. }\end{array}$ & $\begin{array}{c}\text { MtIIcc } \\
0-20 \mathrm{~cm} \\
\text { R3 }\end{array}$ & $Z_{2}$ \\
\hline
\end{tabular}

Achillea millefolium, Agrostis canina, Betula pendula Roth, Calystegiasepium (L.) R.Br,

Cardaminopsisarenosa (L.) Hayek, Carex acuta, C.

hirta L., Centaurea jacea L., Cerastiumholosteoides Fr. em. Hyl., Cirsium arvense, C. oleraceum, Dactylis glomerata L., Daucus carota L.,

Deschampsiacaespitosa, Eupatorium cannabinum L., Festuca arundinacea Schreb., Frangula alnus Mill., Galium album Mill., G. uliginosum, Holcus lanatus, Hypericum tetrapterum Fr., Lycopus europaeus, Lysimachia vulgaris, Mentha aquatica, Molinia caerulea (L.) Moench, Nymphaea alba L., Phleum pratense L., Plantago lanceolata, P. major, Poa pratensis L., P. trivialis L., Potentilla anserine L., Ranunculus repens, Rhamnus catharticus L., Rubus plicatus W. et N., Salix cinerea, Solanum dulcamara, Sonchus arvensis L., Sparganiumramosum L., Taraxacum officinale, Typha latifolia L., Viburnum opulus L.

Sedge-rushes, moorsh soil with peat, strong degree of moorsh process MtIII, deep soil developed with low Carex-wood decomposed (sapric) peat, 10 YR 3/1 very dark gray, angular-fibrus blocky structure. Moorsh horizon strongly drained, subangular blocky microstructure. Well-developed subhorizons M1, M2. Degraded moorsh M3 subhorizon have light identifiable. Moorsh horizon Mt 0-32 cm depth. Polish Hydrogenic Soil

Classification [36]: MtIIIIcc. World Reference Base [37] soil notation: Sapri-Eutric Histosols.
MtIIIcC

0-20 cm $\quad Z_{2} Z_{3}$

R3

Mt-stage of soil moorshification, MtI-weakly moorshified, MtII-medium moorshified, MtIII-strongly moorshified; a-according to classification WRB 2015-Sapri-Eutric Histosols, $Z_{1}$-grain moorsh, $Z_{2}$-peaty moorsh, $Z_{3}$-humic moorsh. 


\subsection{Groundwater Physicochemical Analyses}

Groundwater samples were collected from April to October, once a month, for three years, from the three wells located in shelterbelt: S0, S1, S2 (Figure 1C) and from three wells on peatland: P0, P1 and P2 (Figure 1D). The samples were transported to the laboratory at ca. $4{ }^{\circ} \mathrm{C}$ and stored at $4{ }^{\circ} \mathrm{C}$.

Water $\mathrm{pH}$ values were measured potentiometrically [38]; total dissolved carbon (TDC), dissolved organic carbon (DOC) and dissolved inorganic carbon (DIC) were determined using the TOC 5050A analyzer (Shimadzu, Kyoto, Japan) after filtered through a $0.45 \mu \mathrm{m}$ pore-size filter.

Total nitrogen (total N) in groundwater was determined by the Kjeldahl method, using the Vapodest $10 \mathrm{~s}$ analyzer (Gerhardt, Königswinter, Germany) [38].

Ammonium ions $\left(\mathrm{NH}_{4}{ }^{+}-\mathrm{N}\right)$ were estimated on an ion chromatograph Waters 1515 (Waters, Milford, CT, USA) appointed with a 1515 Isocratic HPLC pump, conductivity detector Waters 432 , a rotary valve $20 \cdot 10^{-6} \mathrm{dm}^{3}$, sample loop and column PRP-X200 $(150 \times 4.1 \mathrm{~mm}$ I.D.-internal diameter) from Hamilton, protected with a guard column $(25 \times 2.3 \mathrm{~mm}$ I.D. $)$

Nitrate ions $\left(\mathrm{NO}_{3}{ }^{-}-\mathrm{N}\right)$ ions concentrations were measured on an ion chromatograph HIC-6A Shimadzu (Shimadzu, Kyoto, Japan) appointed with an LP-6A Isocratic HPLC pump, conductivity detector CDD-6A, a rotary valve with $20 \cdot 10^{-6} \mathrm{dm}^{3}$ sample loop and column PRP-X100 $(150 \times 4.1 \mathrm{~mm}$ I.D. $)$ from Hamilton, protected with a guard column $(25 \times 2.3 \mathrm{~mm}$ I.D.) [38]; organic nitrogen (organic $\mathrm{N}$ ) was calculated by the difference between total $\mathrm{N}$ and $\mathrm{NH}_{4}{ }^{+}-\mathrm{N}$ concentrations.

\section{Results and Discussion}

3.1. $p H$

The $\mathrm{pH}$ values of peatland groundwater from the wells established for this investigation ranged from 6.4 to 7.5 (Table 3). The $\mathrm{pHs}$ of groundwater under shelterbelt ranged from 6.2 to 8.2 (Table 3). All the groundwater samples have slightly acidic to slightly basic properties [38].

Table 3. The range of $\mathrm{pH}$ values in groundwater under peatland and shelterbelt.

\begin{tabular}{cccccccccc}
\hline \multicolumn{3}{c}{ Peatland } & \multicolumn{3}{c}{ pH } \\
\hline \multicolumn{1}{c}{} & \multicolumn{9}{c}{ Shelterbelt } \\
\hline Place & Distance & 1st Year & 2nd Year & 3rd Year & Place & Distance & 1st Year & 2nd Year & 3rd Year \\
\hline P0 & border & $6.5-7.1$ & $6.6-7.0$ & $6.6-7.0$ & S0 & Border & $7.2-7.9$ & $7.2-7.8$ & $6.2-8.2$ \\
P1 & $700 \mathrm{~m}$ & $6.8-7.5$ & $6.8-7.5$ & $6.8-7.5$ & S1 & $62 \mathrm{~m}$ & $7.0-7.5$ & $7.0-7.7$ & $6.5-7.9$ \\
P2 & $1800 \mathrm{~m}$ & $6.4-7.5$ & $6.7-7.2$ & $6.6-7.3$ & S2 & $125 \mathrm{~m}$ & $7.4-8.0$ & $6.8-7.9$ & $7.2-8.1$ \\
\hline
\end{tabular}

\subsection{Carbon}

The content of the two carbon forms in groundwater decreased in line with an increase in the distance from the borders of peatland and shelterbelts, and in line with a groundwater direction flow. These forms are present in organic and inorganic compounds that may exhibit bioavailability for plants and microorganisms. During the entire vegetation season in groundwater under peatland soil TDC concentration ranged from 60.62 to $114.91 \mathrm{mg} \mathrm{L}^{-1}$ and under shelterbelt from 40.80 to $137.20 \mathrm{mg} \mathrm{L}^{-1}$ (Table 4; Figures 2 and 3), respectively. On both peatland and shelterbelt, the decrease in TDC concentration ranged between $-12.98 \%$ and $-23.77 \%$ and between $-34.82 \%$ and $-56.10 \%$ for peatland and shelterbelt, respectively (Table 4 ). 
In addition, similar changes were noted for DOC concentration in groundwater from the wells dug. The highest DOC concentration was recorded at the beginning of the peatland transect ( $48.66 \mathrm{mg} \mathrm{L}^{-1}$ ) and shelterbelt (20.29 $\mathrm{mg} \mathrm{L}^{-1}$ ) (Table 4; Figures 4 and 5). The results showed that the lowest concentrations of DOC were determined in groundwater samples in P0 and S1 points (Figures 4 and 5). Moreover, the investigations revealed that the decrease in DOC concentration ranged $-17.64 \%$ and $-43.22 \%$ on peatland and from $-32.59 \%$ and $-45.21 \%$ on shelterbelt, respectively. These TDC and DOC concentrations decreased together with the increase in the distance between P0 to P2 and S0 to S2 (Table 4, Figure 1C,D), and in line with a groundwater direction flow. This suggests that these two elements of the landscape functioned like biogeochemical barriers; however, the shelterbelt was more efficient than peatland in this context.

Table 4. Mean concentrations of TDC and DOC in groundwater under peatland and shelterbelt soils.

\begin{tabular}{|c|c|c|c|c|c|c|c|c|c|}
\hline \multicolumn{5}{|c|}{ Peatland } & \multicolumn{5}{|c|}{ Shelterbelt } \\
\hline \multicolumn{10}{|c|}{ TDC } \\
\hline Place & Distance & $\begin{array}{l}\text { 1st year } \\
\left(\mathrm{mg} \mathrm{L}^{-1}\right)\end{array}$ & $\begin{array}{l}\text { 2nd year } \\
\left(\mathrm{mg} \mathrm{L}^{-1}\right)\end{array}$ & $\begin{array}{l}\text { 3rd year } \\
\left(\mathrm{mg} \mathrm{L}^{-1}\right)\end{array}$ & Place & Distance & $\begin{array}{l}\text { 1st year } \\
\left(\mathrm{mg} \mathrm{L}^{-1}\right)\end{array}$ & $\begin{array}{l}\text { 2nd year } \\
\left(\mathrm{mg} \mathrm{L}^{-1}\right)\end{array}$ & $\begin{array}{l}\text { 3rd year } \\
\left(\mathrm{mg} \mathrm{L}^{-1}\right)\end{array}$ \\
\hline P0 & Border & 114.91 & 104.82 & 84.73 & So & Border & 137.20 & 134.16 & 88.98 \\
\hline P1 & $700 \mathrm{~m}$ & 113.78 & 83.59 & 60.62 & $\mathrm{~S} 1$ & $62 \mathrm{~m}$ & 40.80 & 44.41 & 43.23 \\
\hline P2 & $1800 \mathrm{~m}$ & 99.99 & 79.90 & 70.75 & $\mathrm{~S} 2$ & $125 \mathrm{~m}$ & 67.83 & 58.89 & 58.00 \\
\hline \multicolumn{2}{|c|}{$(-)$ decr. $/(+)$ incr. } & $-12.98 \%$ & $-23.77 \%$ & $-16.50 \%$ & $(-) \mathrm{d}$ & (+)incr. & $-50.56 \%$ & $-56.10 \%$ & $-34.82 \%$ \\
\hline \multicolumn{10}{|c|}{ DOC } \\
\hline Place & Distance & $\begin{array}{c}\text { 1st year } \\
\left(\mathrm{mg} \mathrm{L}^{-1}\right)\end{array}$ & $\begin{array}{l}\text { 2nd year } \\
\left(\mathrm{mg} \mathrm{L}^{-1}\right)\end{array}$ & $\begin{array}{l}\text { 3rd year } \\
\left(\mathrm{mg} \mathrm{L}^{-1}\right)\end{array}$ & Place & Distance & $\begin{array}{l}\text { 1st year } \\
\left(\mathrm{mg} \mathrm{L}^{-1}\right)\end{array}$ & $\begin{array}{l}\text { 2nd year } \\
\left(\mathrm{mg} \mathrm{L}^{-1}\right)\end{array}$ & $\begin{array}{l}\text { 3rd year } \\
\left(\mathrm{mg} \mathrm{L}^{-1}\right)\end{array}$ \\
\hline P0 & Border & 48.66 & 44.21 & 30.62 & So & Border & 20.24 & 20.10 & 20.28 \\
\hline P1 & $700 \mathrm{~m}$ & 40.65 & 36.66 & 25.72 & $\mathrm{~S} 1$ & $62 \mathrm{~m}$ & 6.26 & 9.47 & 12.28 \\
\hline $\mathrm{P} 2$ & $1800 \mathrm{~m}$ & 27.63 & 28.43 & 25.22 & $\mathrm{~S} 2$ & $125 \mathrm{~m}$ & 11.09 & 12.16 & 13.67 \\
\hline \multicolumn{2}{|c|}{$(-)$ decr. $/(+)$ incr. } & $-43.22 \%$ & $-35.69 \%$ & $-17.64 \%$ & \multicolumn{2}{|c|}{$(-)$ decr. $/(+)$ incr. } & $-45.21 \%$ & $-39.50 \%$ & $-32.59 \%$ \\
\hline
\end{tabular}

Percentage (-)decrease/(+)increase in chemical compounds concentration in groundwater after passing through biogeochemical barriers.

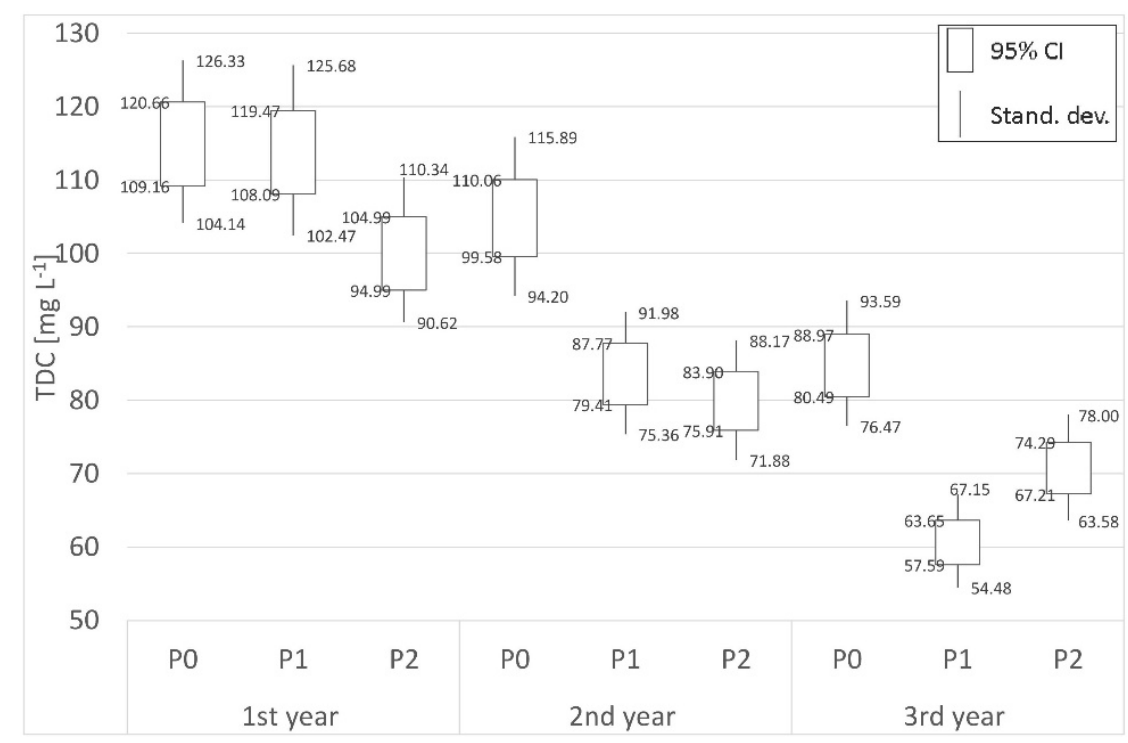

Figure 2. The concentrations of TDC in groundwater under peatland soils ( $\square-95 \%$ confidence interval, I-standard deviation). 


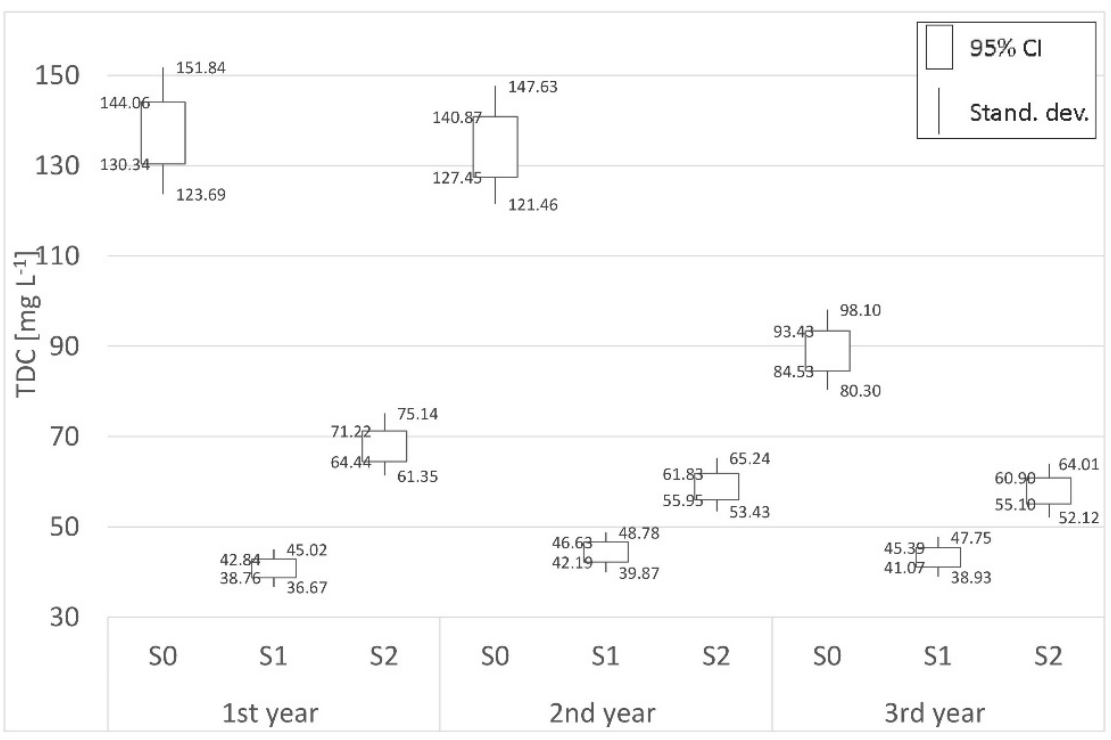

Figure 3. The concentrations of TDC in groundwater under shelterbelt.

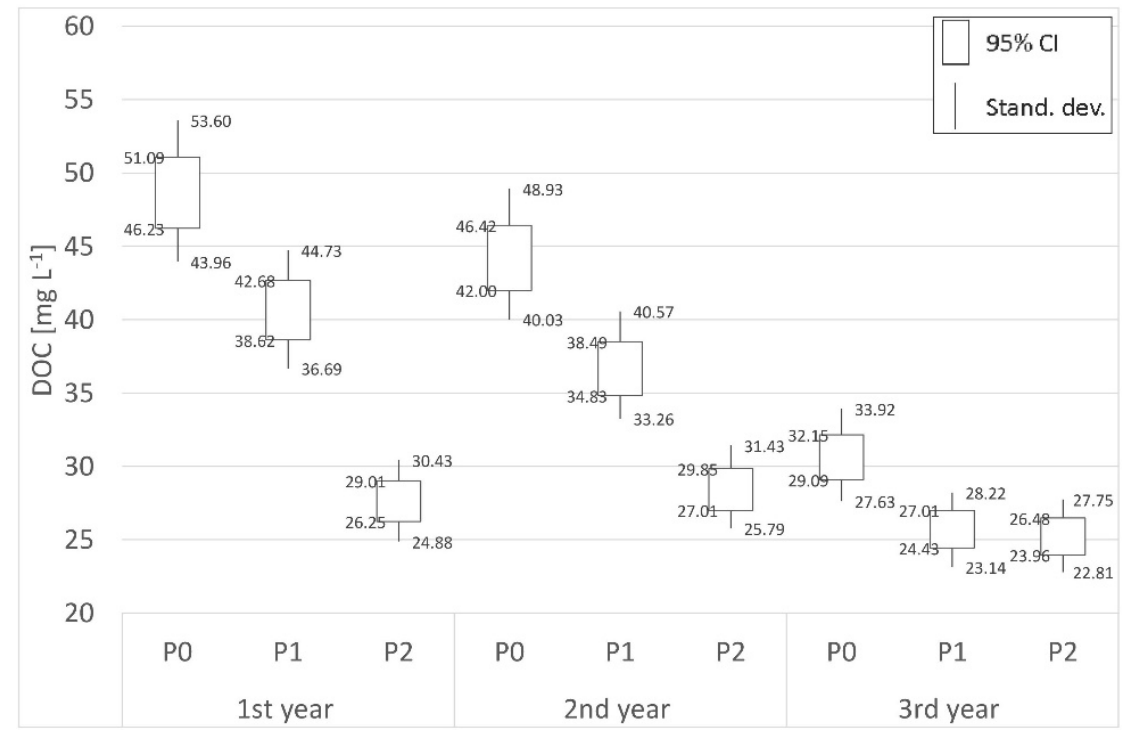

Figure 4. The concentrations of DOC in groundwater under peatland soils.

The barrier function of shelterbelts and peatlands can be limited first of all by the litter decomposition processes, which create more soluble organic matter and the leaching of a considerable quantity of DOC into groundwater. Those processes are controlled by: (1) abiotic factors, such as climate and (2) biotic factors, such as litter chemical composition and soil organisms.

It is also universally recognized that there are two fundamental processes through which decomposition occurs: (1) the mineralization and humification of lignin, cellulose and other compounds by a succession of microorganisms and (2) the leaching of soluble compounds into the soil whose carbon and nitrogen are mineralized or immobilized. As decomposition proceeds, the litter becomes enriched, among the other components, lignin and nitrogen. Moreover, increasing lignin concentrations during litter decomposition results in the decomposition rates being suppressed [39]. In these processes, recalcitrant organic compounds are formed and the DOC may be eluted through the mineral soil into the groundwater. 


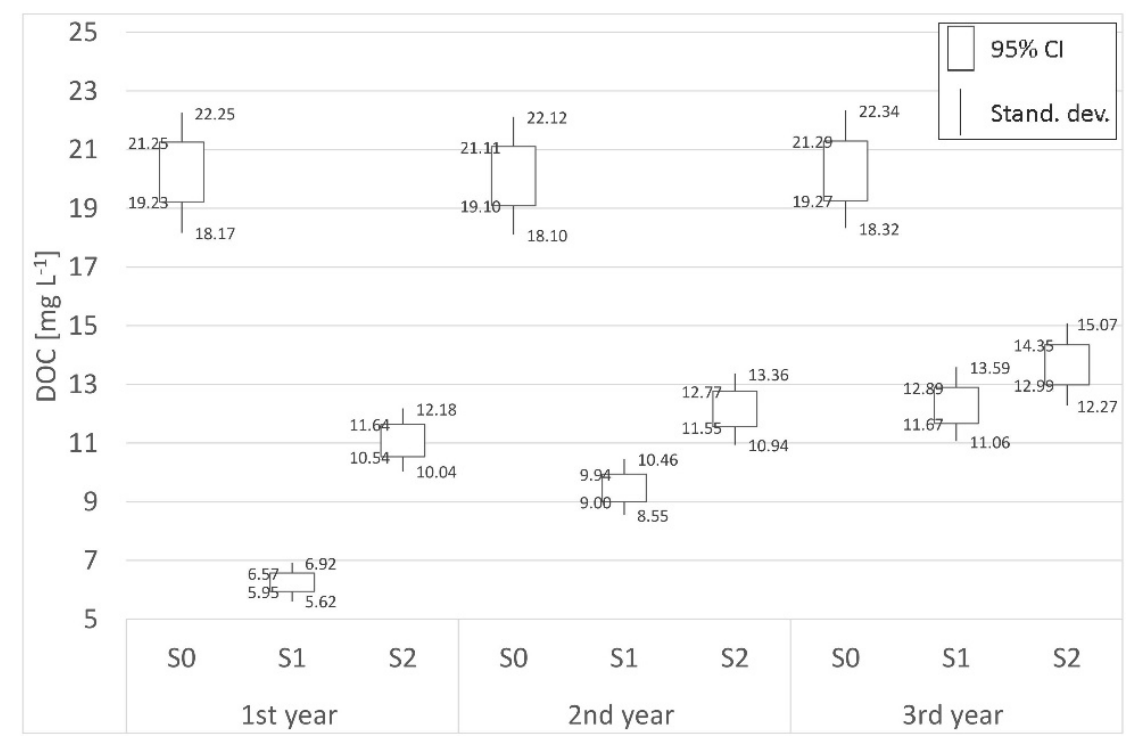

Figure 5. The concentrations of DOC in groundwater under shelterbelt soils.

Bernacki [40] compared the litter decomposition rates in three forest plots: (i) a 150-year old oak-hornbeam tree stand, (ii) young mixed trees (approximately 50 years), and (iii) a new (one year) waterfront stand. This author showed the highest rate of decomposition in a new shelterbelt and the lowest in the oak-hornbeam afforestation. The rate of this process depends on respective species composition, resulting in chemical diversity related to phosphorus content and N/P ratios of the litter and precipitation level.

As was shown in studies by Licznar et al. [41], plant cover and climatic conditions, especially the size of atmospheric precipitation, affect the properties of humic compounds. The changing humidity and oxidation-reduction conditions influence the transformations of organic matter, especially in hydrogenic soils [42]. Moreover, Chittleborough et al. [43], in field trials revealed that periodic drought, temperature and amount of precipitation were positively correlated with the leaching of DOC to groundwater after rainless periods. Decomposition of soil organic matter owing to tillage activities also contributes to the release of various chemical compounds from the soil [25].

Shelterbelts more than peatlands, especially with strongly developed tree roots, significantly limit the penetration of DOC into groundwater. Burzyńska [44] detected a statistically significant correlation $(r=0.83)$ between the DOC content in the soil and shallow groundwater collected in the rural homesteads of the Masovian Voivodeship. According to the author, the method of using meadow soils, including the applied agrotechnical measures, e.g., mowing and leaving fragmented vegetation in the meadow, may affect the dynamics and course of the organic matter decomposition process, as well as the release and infiltration of DOC into groundwater. This indicates that the process of the accumulation of organic matter in peatland and shelterbelt soils is not limited. Moreover, catabolic processes of organic compounds are not dominating and not leading to the supply of this compound into groundwater.

Furthermore, Życzyńska-Bałoniak et al. [45], Szajdak et al. [4], and Meysner et al. [46] have defined that a $16.5 \mathrm{~m}$ width of shelterbelt is the most efficient dimension for decreasing organic carbon and humic substances content in groundwater after its penetration, 55$63 \%$ and $69-79 \%$, respectively. One of the reasons for the unequal decrease in a chemical substance passing through different distances of the shelterbelt is the different properties of the mineral and mineral-organic soils of forest island. 
The study by Szajdak and Szczepański [47] showed that the process of the release of organic matter from peat was compatible with the first-order reaction model. The authors calculated the first-order reaction rate constant $(\mathrm{k})$ and half time $\left(\mathrm{t}_{0.5}\right)$ of the leaching processes for non-decomposed forms of lignin, substances in initial decomposition and fully humified organic matter (Table 5). These studies indicated that the flow of groundwater was accompanied by a decrease in DOC concentration, from the P0 to P2 points, by $-43.22 \%$, $-35.69 \%$, and $-17.64 \%$ respectively in all periods of sampling in the peatlands (Table 4 ; Figures 4 and 5).

Table 5. Pseudo-first-order rate constants $\left(\mathrm{k} \times 10^{-4} \mathrm{~s}^{-1}\right)$, half-times $\left(\mathrm{t}_{0.5}, \mathrm{~min}\right)$, and correlation coefficients ( $r$ ) for the reaction of the release of organic matter from peat [47].

\begin{tabular}{cccc}
\hline \multirow{2}{*}{ Kind of Organic Matter } & \multicolumn{1}{c}{ Place of Sampling } & P2 \\
\cline { 2 - 4 } & $\mathrm{P0}$ & $\mathbf{P 1}$ & $\mathrm{k}=2.6832$ \\
Non-decomposed forms of lignin & $\mathrm{k}=2.8549$ & $\mathrm{k}=2.6534$ & $\mathrm{t}_{0.5}=43.1$ \\
& $\mathrm{r}=-0.989$ & $\mathrm{t}_{0.5}=43.7$ & $\mathrm{r}=-0.967$ \\
\hline Substances in initial & $\mathrm{k}=2.9089$ & $\mathrm{k}=2.4593$ & $\mathrm{k}=2.3045$ \\
decomposition & $\mathrm{t}_{0.5}=39.7$ & $\mathrm{t}_{0.5}=47.0$ & $\mathrm{t}_{0.5}=50.1$ \\
& $\mathrm{r}=-0.989$ & $\mathrm{r}=-0.985$ & $\mathrm{r}=-0.986$ \\
\hline \multirow{2}{*}{ Fully humified organic matter } & $\mathrm{k}=2.7361$ & $\mathrm{k}=1.9524$ & $\mathrm{k}=2.3394$ \\
& $\mathrm{t}(0.5=42.2$ & $\mathrm{t}_{0.5}=59.2$ & $\mathrm{t}_{0.5}=49.4$ \\
& $\mathrm{r}=-0.944$ & $\mathrm{r}=-0.925$ & $\mathrm{r}=-0.897$ \\
\hline
\end{tabular}

In addition, the concentration of DOC and dissolved organic matter in groundwater is dependent on the contrary processes of leaching and accumulation, and dissolved salts [48]. Earlier studies of Szajdak and Szczepański [47], on the leaching of organic matter, indicated a decreasing rate of leaching process of organic matter from P0 to P2 (Table 5), from 40.5 to $42.2 \mathrm{~min}$ for P0, from 43.7 to $59.2 \mathrm{~min}$ for P1 and from 43.1 to $49.4 \mathrm{~min}$ for P2 respectively and hence an increasing peatland efficiency as a biogeochemical barrier. Therefore, it can be said that DOC concentration in groundwater is dependent on leaching and accumulation processes. Moreover, the influence of dissolved salts on dissolved organic matter release was shown by Reemtsma et al. [48].

\subsection{Nitrogen}

The total $\mathrm{N}$ concentration in groundwater of peatland and shelterbelts does not present a wide range, with a minimum value of $9.06 \mathrm{mg} \mathrm{L}^{-1}$ and a maximum of $20.80 \mathrm{mg} \mathrm{L}^{-1}$. The experimental data showed total $\mathrm{N}$ content on peatland was reduced between $-7.63 \%$ and $-18.35 \%$ from P0 to P2 sites while on shelterbelt was limited between $-17.71 \%$ and $-36.76 \%$ from S0 to S2 sites (Table 6; Figures 6 and 7). The results showed that total $\mathrm{N}$ elimination processes may function better on shelterbelt than peatland, although shelterbelt groundwater is polluted even two times more. This means that the intensity of organic matter decomposition and immobilization of nitrogen plays an important role in determining the control capacity of peatlands and shelterbelts [49].

The lowest values of $\mathrm{NO}_{3}{ }^{-}-\mathrm{N}$ concentrations were observed on peatland from 0.55 to $1.03 \mathrm{mg} \mathrm{L}^{-1}$ and the highest on shelterbelt from 9.06 to $20.18 \mathrm{mg} \mathrm{L}^{-1}$ (Table 6; Figures 8 and 9). In addition, $\mathrm{NO}_{3}{ }^{-}-\mathrm{N}$ concentrations decreased from the border of peatland and shelterbelt (ranged between $-11.25 \%$ and $-40.46 \%$, and $-22.11 \%$ and $-40.21 \%$, respectively) (Table 6). This suggests that these two elements of the landscape function as biogeochemical barriers. The lower values of $\mathrm{NO}_{3}{ }^{-}-\mathrm{N}$ concentrations in groundwater of peatland can indicate more intensive denitrification processes in soil. The structures of peatland with a high groundwater level favor anaerobic processes without oxygen access [50]. 
Table 6. Mean concentrations of total $\mathrm{N}, \mathrm{NO}_{3}{ }^{-}-\mathrm{N}, \mathrm{NH}_{4}{ }^{+}-\mathrm{N}$ and organic $\mathrm{N}$ in groundwater under peatland and shelterbelt soil.

\begin{tabular}{|c|c|c|c|c|c|c|c|c|c|}
\hline \multicolumn{5}{|c|}{ Peatland } & \multicolumn{5}{|c|}{ Shelterbelt } \\
\hline \multicolumn{10}{|c|}{ Total N } \\
\hline Place & Distance & $\begin{array}{l}\text { 1st year } \\
\left(\mathrm{mg} \mathrm{L}^{-1}\right)\end{array}$ & $\begin{array}{l}\text { 2nd year } \\
\left(\mathrm{mg} \mathrm{L}^{-1}\right)\end{array}$ & $\begin{array}{l}\text { 3rd year } \\
\left(\mathrm{mg} \mathrm{L}^{-1}\right)\end{array}$ & Place & Distance & $\begin{array}{l}\text { 1st year } \\
\left(\mathrm{mg} \mathrm{L}^{-1}\right)\end{array}$ & $\begin{array}{l}\text { 2nd year } \\
\left(\mathrm{mg} \mathrm{L}^{-1}\right)\end{array}$ & $\begin{array}{l}\text { 3rd year } \\
\left(\mathrm{mg} \mathrm{L}^{-1}\right)\end{array}$ \\
\hline P0 & Border & 11.23 & 12.28 & 12.50 & SO & Border & 20.80 & 11.01 & 15.48 \\
\hline P1 & $700 \mathrm{~m}$ & 11.55 & 11.65 & 11.55 & S1 & $62 \mathrm{~m}$ & 15.24 & 10.89 & 12.15 \\
\hline $\mathrm{P} 2$ & $1800 \mathrm{~m}$ & 10.37 & 10.36 & 10.20 & S2 & $125 \mathrm{~m}$ & 16.23 & 9.06 & 9.79 \\
\hline \multicolumn{2}{|c|}{$(-)$ decr. $/(+)$ incr. } & $-7.63 \%$ & $-15.64 \%$ & $-18.35 \%$ & $(-) \mathrm{de}$ & (+)incr. & $-21.97 \%$ & $-17.71 \%$ & $-36.76 \%$ \\
\hline \multicolumn{10}{|c|}{$\mathrm{NO}_{3}{ }^{-}-\mathrm{N}$} \\
\hline Place & Distance & $\begin{array}{c}\text { 1st year } \\
\left(\mathrm{mg} \mathrm{L}^{-1}\right)\end{array}$ & $\begin{array}{l}\text { 2nd year } \\
\left(\mathrm{mg} \mathrm{L}^{-1}\right)\end{array}$ & $\begin{array}{l}\text { 3rd year } \\
\left(\mathrm{mg} \mathrm{L}^{-1}\right)\end{array}$ & Place & Distance & $\begin{array}{l}\text { 1st year } \\
\left(\mathrm{mg} \mathrm{L}^{-1}\right)\end{array}$ & $\begin{array}{l}\text { 2nd year } \\
\left(\mathrm{mg} \mathrm{L}^{-1}\right)\end{array}$ & $\begin{array}{l}\text { 3rd year } \\
\left(\mathrm{mg} \mathrm{L}^{-1}\right)\end{array}$ \\
\hline P0 & Border & 0.69 & 0.79 & 1.03 & SO & Border & 12.03 & 7.60 & 13.08 \\
\hline P1 & $700 \mathrm{~m}$ & 0.61 & 0.56 & 0.74 & S1 & $62 \mathrm{~m}$ & 8.61 & 7.94 & 10.27 \\
\hline P2 & $1800 \mathrm{~m}$ & 0.55 & 0.70 & 0.62 & $\mathrm{~S} 2$ & $125 \mathrm{~m}$ & 8.20 & 5.92 & 7.82 \\
\hline \multicolumn{2}{|c|}{ (-)decr./(+)incr. } & $-20.30 \%$ & $-11.25 \%$ & $-40.46 \%$ & $(-) \mathrm{d}$ & $(+)$ incr. & $-31.84 \%$ & $-22.11 \%$ & $-40.21 \%$ \\
\hline \multicolumn{10}{|c|}{$\mathrm{NH}_{4}{ }^{+}-\mathrm{N}$} \\
\hline Place & Distance & $\begin{array}{c}\text { 1st year } \\
\left(\mathrm{mg} \mathrm{L}^{-1}\right)\end{array}$ & $\begin{array}{l}\text { 2nd year } \\
\left(\mathrm{mg} \mathrm{L}^{-1}\right)\end{array}$ & $\begin{array}{l}\text { 3rd year } \\
\left(\mathrm{mg} \mathrm{L}^{-1}\right)\end{array}$ & Place & Distance & $\begin{array}{c}\text { 1st year } \\
\left(\mathrm{mg} \mathrm{L}^{-1}\right)\end{array}$ & $\begin{array}{l}\text { 2nd year } \\
\left(\mathrm{mg} \mathrm{L}^{-1}\right)\end{array}$ & $\begin{array}{l}\text { 3rd year } \\
\left(\mathrm{mg} \mathrm{L}^{-1}\right)\end{array}$ \\
\hline P0 & Border & 5.35 & 4.98 & 4.78 & SO & Border & 3.11 & 1.88 & 1.40 \\
\hline $\mathrm{P} 1$ & $70 \mathrm{~m}$ & 5.67 & 4.64 & 3.75 & S1 & $62 \mathrm{~m}$ & 3.42 & 2.12 & 1.40 \\
\hline $\mathrm{P} 2$ & $1800 \mathrm{~m}$ & 3.35 & 3.02 & 2.84 & $\mathrm{~S} 2$ & $125 \mathrm{~m}$ & 3.67 & 2.15 & 1.45 \\
\hline \multicolumn{2}{|c|}{ (-)decr. $/(+)$ incr. } & $-37.42 \%$ & $-39.42 \%$ & $-40.60 \%$ & $(-) \mathrm{d}$ & $(+)$ incr. & $+18.01 \%$ & $+14.36 \%$ & $+3.57 \%$ \\
\hline \multicolumn{10}{|c|}{ Organic $\mathbf{N}$} \\
\hline Place & Distance & $\begin{array}{c}\text { 1st year } \\
\left(\mathrm{mg} \mathrm{L}^{-1}\right)\end{array}$ & $\begin{array}{l}\text { 2nd year } \\
\left(\mathrm{mg} \mathrm{L}^{-1}\right)\end{array}$ & $\begin{array}{l}\text { 3rd year } \\
\left(\mathrm{mg} \mathrm{L}^{-1}\right)\end{array}$ & Place & Distance & $\begin{array}{l}\text { 1st year } \\
\left(\mathrm{mg} \mathrm{L}^{-1}\right)\end{array}$ & $\begin{array}{l}\text { 2nd year } \\
\left(\mathrm{mg} \mathrm{L}^{-1}\right)\end{array}$ & $\begin{array}{l}\text { 3rd year } \\
\left(\mathrm{mg} \mathrm{L}^{-1}\right)\end{array}$ \\
\hline P0 & Border & 5.19 & 6.51 & 6.68 & SO & Border & 5.66 & 1.53 & 1.00 \\
\hline P1 & $700 \mathrm{~m}$ & 5.27 & 6.45 & 7.07 & S1 & $62 \mathrm{~m}$ & 3.22 & 0.83 & 0.48 \\
\hline $\mathrm{P} 2$ & $1800 \mathrm{~m}$ & 6.47 & 6.64 & 6.75 & $\mathrm{~S} 2$ & $125 \mathrm{~m}$ & 4.36 & 0.99 & 0.52 \\
\hline \multicolumn{2}{|c|}{$(-)$ decr. $/(+)$ incr. } & $+24.78 \%$ & $+2.01 \%$ & $+1.01 \%$ & $(-) \mathrm{d}$ & $(+)$ incr. & $-22.97 \%$ & $-35.29 \%$ & $-48.00 \%$ \\
\hline
\end{tabular}

Percentage of $(-)$ decrease/(+)increase in chemical compound concentration in groundwater after passing through the biogeochemical barriers.

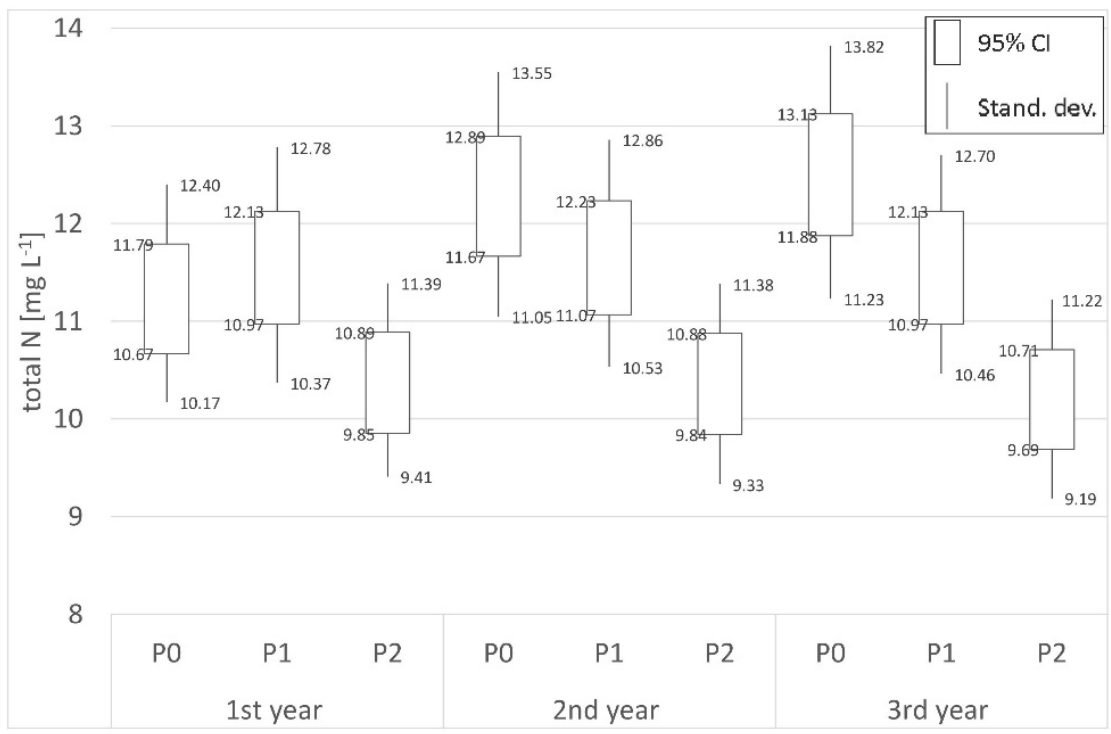

Figure 6. The concentrations of total $\mathrm{N}$ in groundwater under peatland soils. 


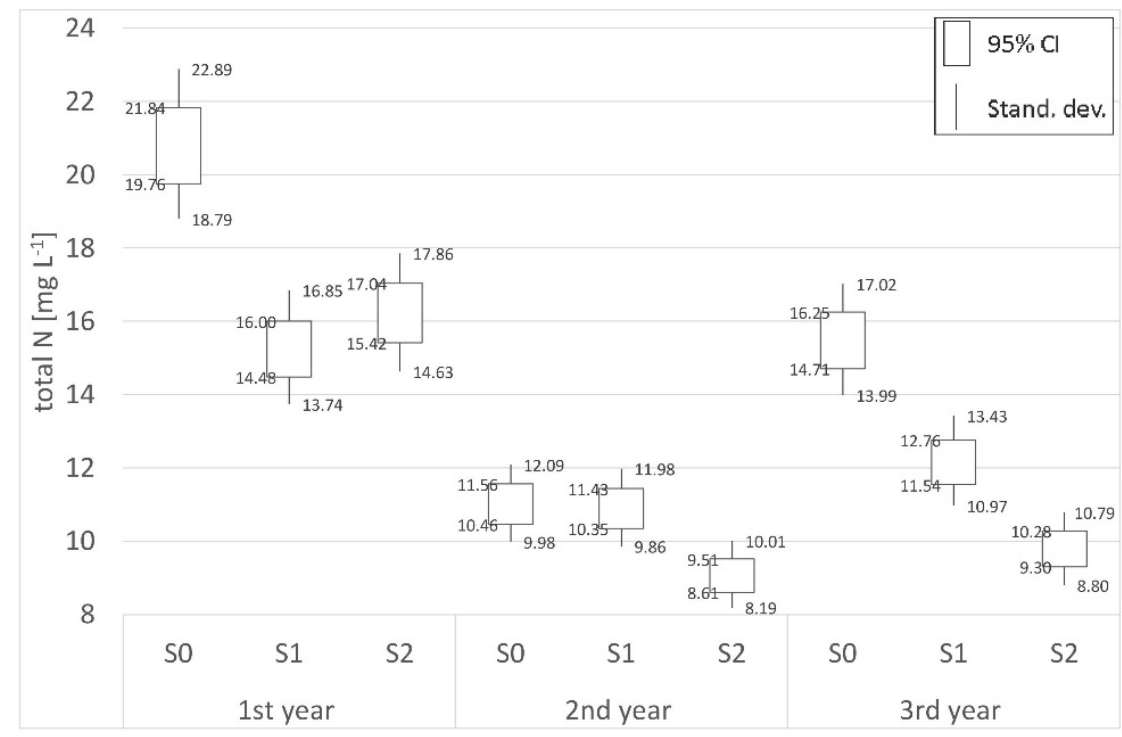

Figure 7. The concentrations of total $\mathrm{N}$ in groundwater under shelterbelt soils.

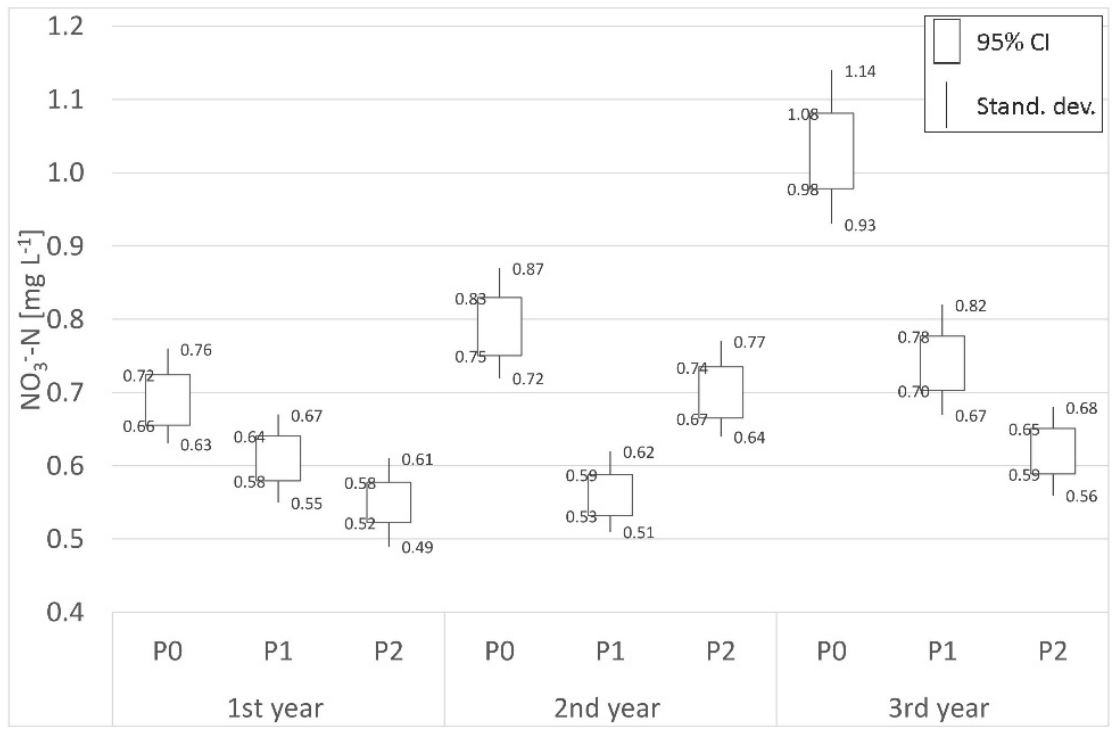

Figure 8. The concentrations of $\mathrm{NO}_{3}{ }^{-}-\mathrm{N}$ in groundwater under peatland soils.

Measured $\mathrm{N}$ losses through denitrification in peat soils appear to be of the same magnitude as $\mathrm{N}$ losses through denitrification in other soil types [51,52]. This is remarkable, since circumstances for denitrification seem more favorable in peat soils than in other soils, considering the often anaerobic and organic matter-rich conditions. Most estimates of $\mathrm{N}$ losses through denitrification on different soil types, including peat soils, are based on measurements in the topsoil only $(0-20 \mathrm{~cm})$. The presence of $\mathrm{NO}_{3}{ }^{-}-\mathrm{N}$, degradable $\mathrm{C}$ and anaerobic conditions, only occur concurrently in the topsoil [53]. According to Jorgensen and Richter [54], in peatland soils, high contents of degradable $C$ are also present in the subsoil. Therefore, a considerable contribution of $\mathrm{N}$ losses through denitrification from the subsoil can be expected in peat soils when $\mathrm{NO}_{3}{ }^{-}-\mathrm{N}$ is present under anaerobic conditions.

Moreover, DOC, which is found in concentrations 2-6 times higher in peatland than shelterbelt groundwater, is responsible for attaching inorganic forms of nitrogen (Tables 5 and 6) [55]. The study of Ryszkowski and Kędziora [23] similarly revealed that $\mathrm{NO}_{3}{ }^{-}-\mathrm{N}$ concentrations dropped substantially when groundwater outgoing from cultivated fields has flowed under shelterbelts. Authors introduced the $\mathrm{NO}_{3}{ }^{-}-\mathrm{N}$ concentration, ranging from 0.3 to $8.4 \mathrm{mg} \mathrm{L}^{-1}$ under shelterbelts and from 12.6 to $94.2 \mathrm{mg} \mathrm{L}^{-1}$ under adjoining cultivated fields. Concentrations of incoming $\mathrm{NO}_{3}{ }^{-}-\mathrm{N}$ with groundwater decreased 
by $75.6 \%$ to $97.7 \%$ of input in six objects composed of cultivated fields and adjoining shelterbelts. The observed changes can also be explained by the influence of plant cover that effectively restrains the migration of various substances from the soil solution. Our research has shown that one point of investigated peatland, P2, is covered by highly nitrophilous plants (Table 3).

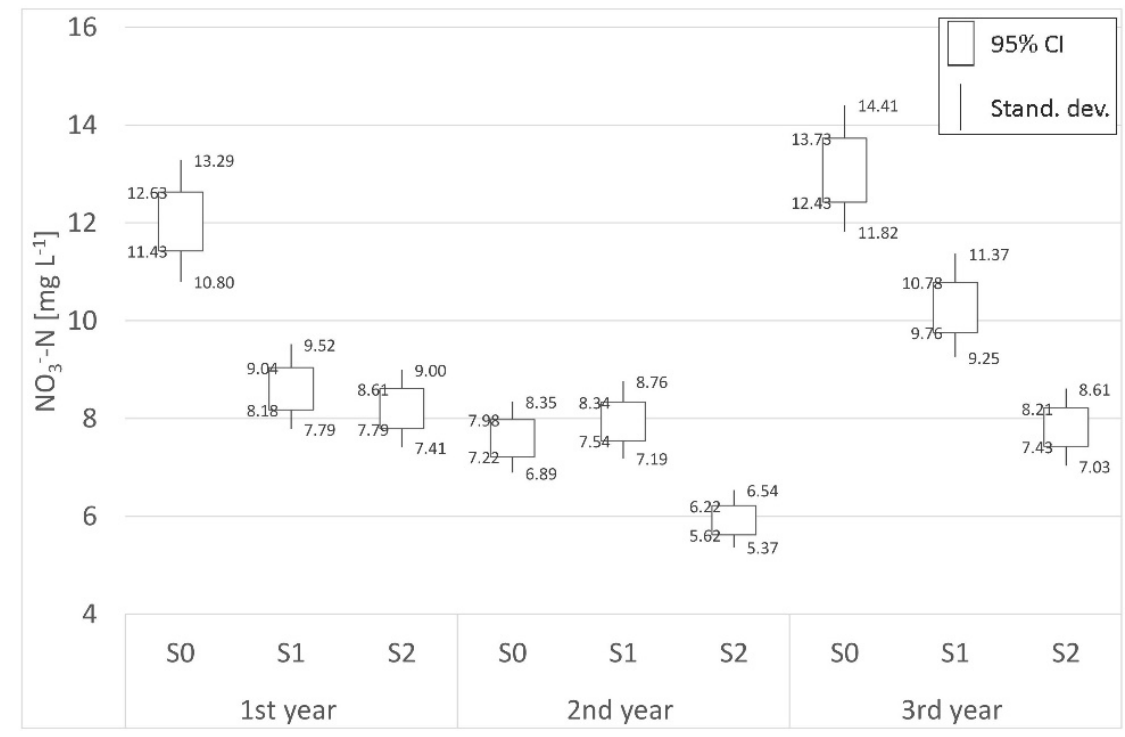

Figure 9. The concentrations of $\mathrm{NO}_{3}{ }^{-}-\mathrm{N}$ in groundwater under shelterbelt soils.

The concentrations of $\mathrm{NH}_{4}{ }^{+}-\mathrm{N}$ ranged from 1.40 to $5.67 \mathrm{mg} \mathrm{L}^{-1}$ and were similar for groundwater samples of both agricultural elements, decreasing with the increase in peatland transect length from the P0 to P2 point between $-37.48 \%$ and $-40.60 \%$ (Table 6 ; Figure 10) and demonstrating a barrier function. Moreover, the shelterbelt affected an increase in $\mathrm{NH}_{4}{ }^{+}-\mathrm{N}$ concentration between $3.57 \%$ and $18.01 \%$ (Table 6; Figure 11). These results were in line with Ryszkowski and Kẹdziora [23], their studies indicating concentrations of $\mathrm{NH}_{4}{ }^{+}-\mathrm{N}$ have ranged from 1.1 to $4.5 \mathrm{mg} \mathrm{L}^{-1}$ on shelterbelts and from 1.4 to $2.5 \mathrm{mg} \mathrm{L}^{-1}$ on adjoining cultivated fields respectively. In contrast to $\mathrm{NO}_{3}{ }^{-}-\mathrm{N}$, in half of the six studied places, $\mathrm{NH}_{4}{ }^{+}-\mathrm{N}$ concentrations increased on shelterbelts but in the other three decreased between $-15.4 \%$ and $-22.3 \%$.

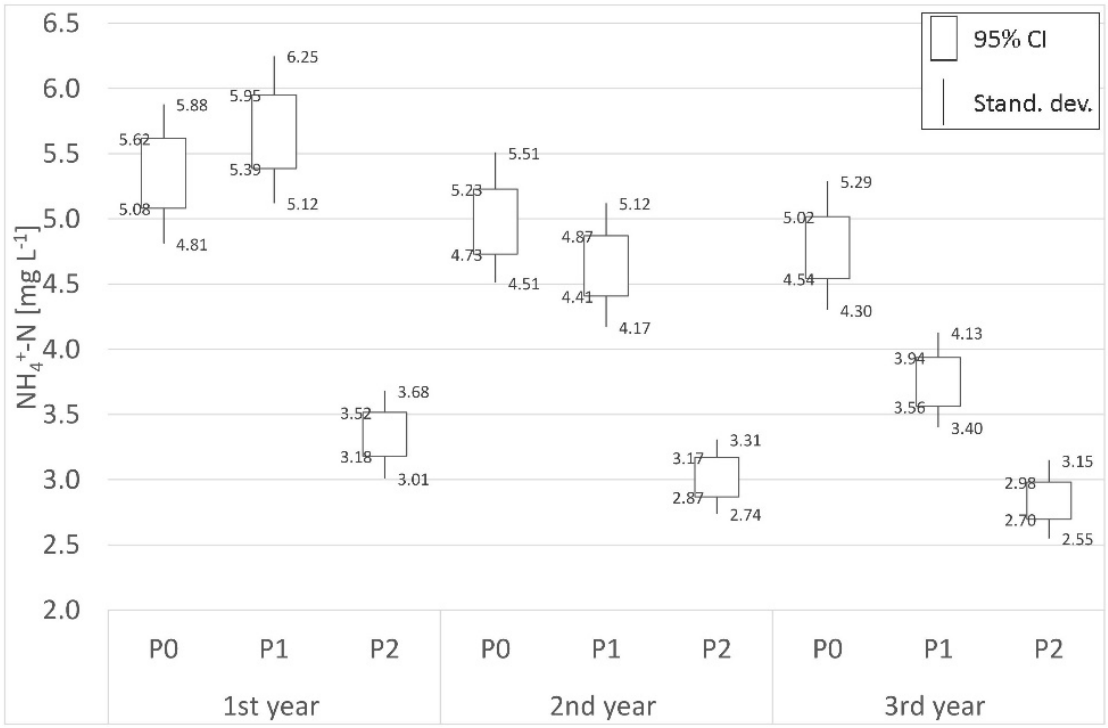

Figure 10. The concentrations of $\mathrm{NH}_{4}{ }^{+}-\mathrm{N}$ in groundwater under peatland soils. 


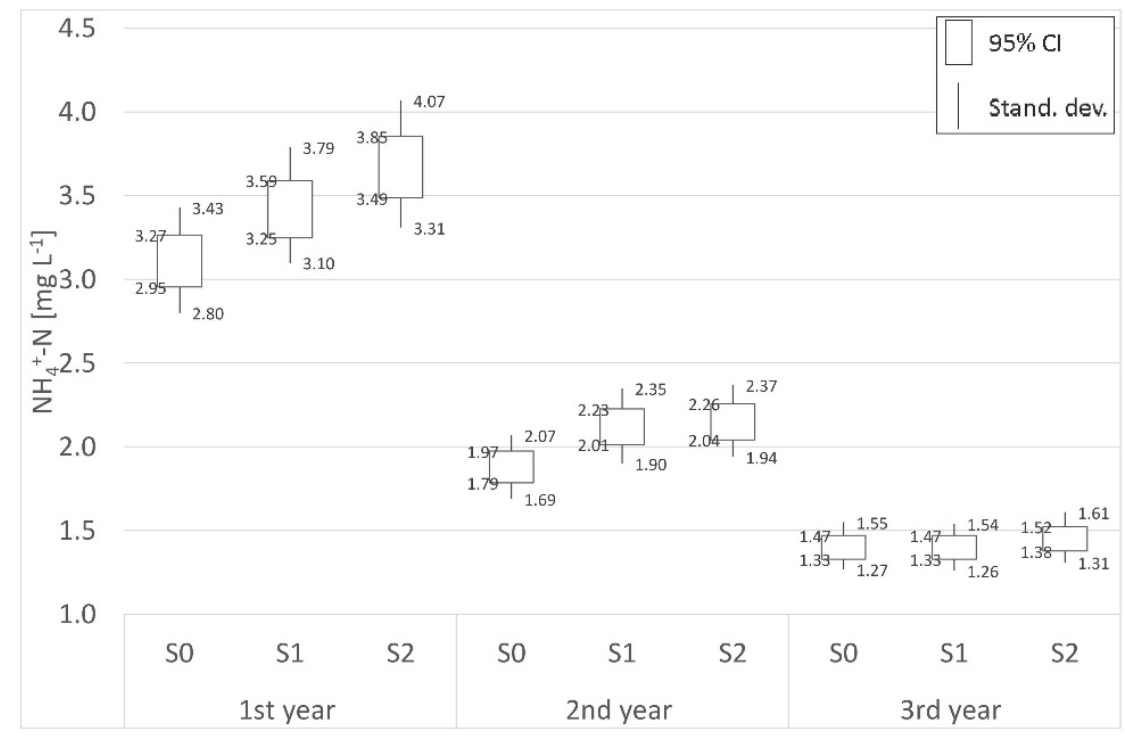

Figure 11. The concentrations of $\mathrm{NH}_{4}{ }^{+}-\mathrm{N}$ in groundwater under shelterbelt soils.

Ammonium ions are taken by the roots system and absorbed by the base exchanges complex. The lack of the decrease in $\mathrm{NH}_{4}{ }^{+}-\mathrm{N}$ ions concentrations when groundwater passes through root systems of the shelterbelts are connected with inputs of $\mathrm{NH}_{4}{ }^{+}-\mathrm{N}$ ions from decomposing organic matter. Several biological mechanisms, conversions and pathways lead to the formation of $\mathrm{NH}_{3}-\mathrm{N}$. One is the dissimilatory nitrate reduction in which $\mathrm{NH}_{3}-\mathrm{N}$ is used for the production of biomass. However, the biomass after mineralization can release ammonium ions. Moreover, a dissimilatory reduction in nitrates takes place, which in denitrification releases $\mathrm{NH}_{4}{ }^{+}-\mathrm{N}$ ions under anaerobic conditions [56]. In addition, very small amounts of $\mathrm{NH}_{4}{ }^{+}-\mathrm{N}$ ions can be exuded from tree roots, as shown experimentally by Smith [57] in the case of birch, beech and maple trees.

The results of Ryszkowski et al. [58] and Ryszkowski [20] indicate that during warm and wet years significant litter degradation in afforestation is observed, which is the reason for significant nitrogen inflow to the soil and groundwater.

Our investigations have proved that for organic $\mathrm{N}$ only shelterbelt functions as biogeochemical barriers, while peatland is the source (Figures 12 and 13). During the research, the decrease in organic $\mathrm{N}$ concentration levels ranged between $-22.97 \%$ and $-48.00 \%$ (Table 6; Figure 13) with an associated increase in distance from the edge of the shelterbelt (from point S0 to S2). While the opposite trend was observed on peatland and a $24.78 \%$ increase was found (from 5.19 to $6.47 \mathrm{mg} \mathrm{L}^{-1}$ ) (Table 6; Figure 12). The better aerobic conditions of soil, for mineralization processes of organic $\mathrm{N}$ under shelterbelt, can lead to an increase in the $\mathrm{NH}_{4}{ }^{+}-\mathrm{N}$ concentrations in groundwater, which has been shown above (Table 6) [59]. It would appear therefore that immobilization processes of nitrogen inorganic forms on shelterbelt lead to the formation of simple organic $\mathrm{N}$ substances, which can be more easily eluted from the soil to groundwater. 


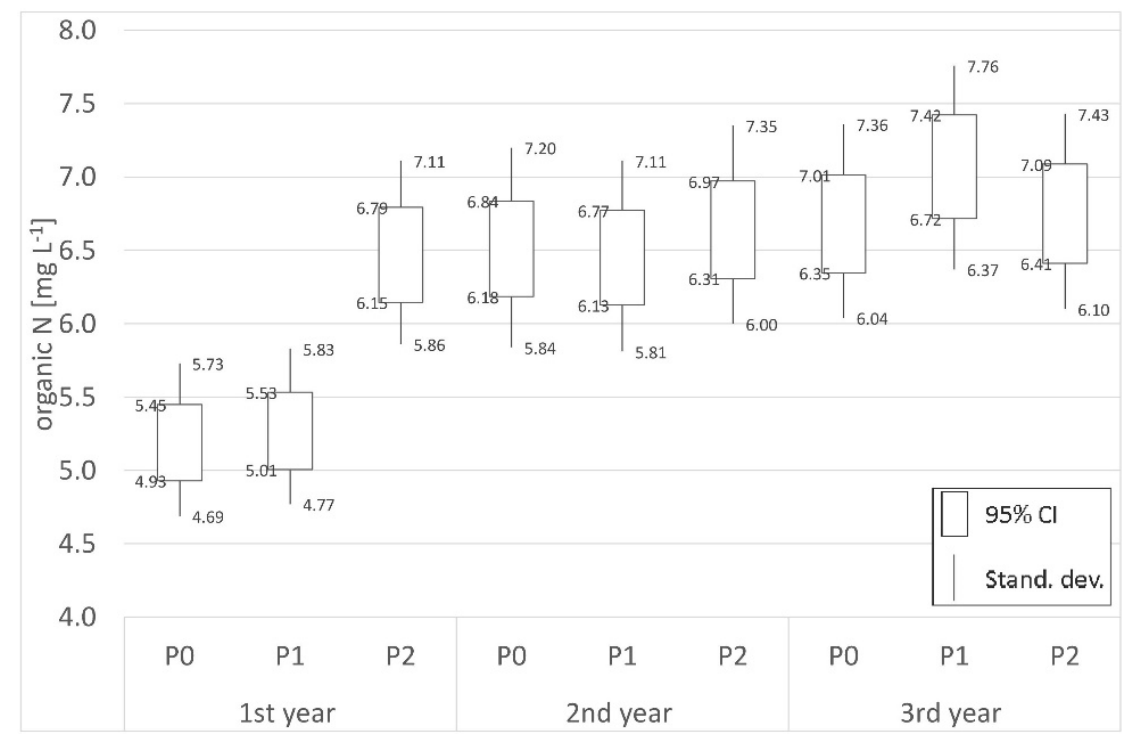

Figure 12. The concentrations of organic $\mathrm{N}$ in groundwater under peatland soils.

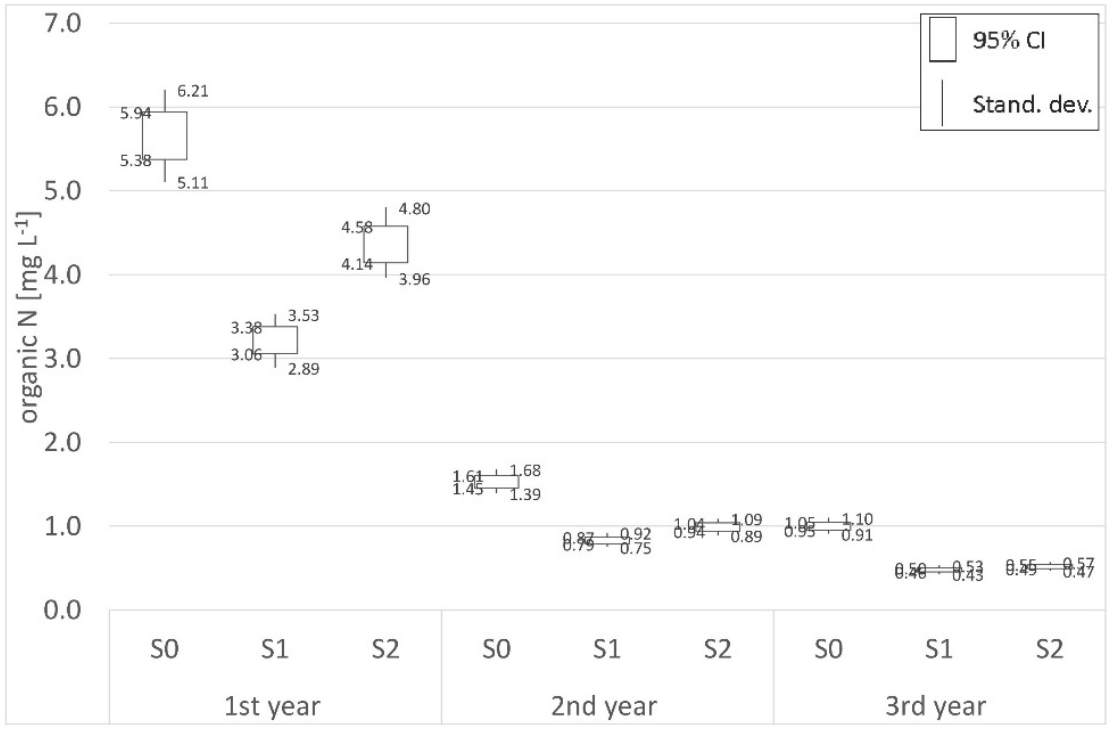

Figure 13. The concentrations of organic $\mathrm{N}$ in groundwater under shelterbelt soils.

\section{Conclusions and Future Directions}

A significant barrier efficiency for the spread of NSP in groundwater under peatland and shelterbelt ecosystems was found, with the increase in the distance between P0 to P2 and S0 to S2, and in line with the groundwater direction flow. (Figures 2-13).

Our study has indicated that peatlands and shelterbelts are a very effective element of the landscape for the removal of dissolving organic carbon and nitrogen compounds from through-flow waters when the nitrogen is in the form of nitrate rather than $\mathrm{NH}_{4}{ }^{+}-\mathrm{N}$ or dissolved organic $\mathrm{N}$.

Moreover, our investigation has suggested that the creation of new multispecies shelterbelts and the protection of peatlands are positive factors that restrict the migration of chemicals in the agricultural landscape.

We recommend therefore a rural countryside water conservation management system through the introduction of shelterbelts as more effective biogeochemical barriers than peatlands, in addition to the other positive functions of the former, which leads to the modification of biochemical soil conditions and finally, a decrease in groundwater NSP content. The removal of NSP from groundwater is still an elusive issue, but it is generally assumed that the following processes are important: plant uptake, ion exchange 
capacities, biological and chemical transformation mechanisms, the inclusion of microbial processes and phytochemical degradation reactions, decomposition and loss of organic matter through biomineralization in the surface layer.

These processes are responsible for biological conversion, biochemical and chemical degradation and reduction. When considering all of the ecological services, constructed shelterbelts should be promoted as an integral component of the manmade farmscape in water conservation and management.

It should be emphasized that the current agricultural and economic policy contributes to the degradation of the environment. In order to ensure sustainable development of agriculture, the principle of a compromise between economic and ecological rules should be followed, by introducing new shelterbelts, peatland protection, and increasing the water retention of the habitats. Our research on the functioning of biogeochemical barriers may contribute to the development of a program of the environmental protection strategy and nonpoint pollution control.

Author Contributions: Conceptualization, L.W.S.; methodology, L.W.S.; writing—original draft preparation, L.W.S.; writing — review and editing, L.W.S.; supervision, L.W.S.; funding acquisition, L.W.S.; formal analysis, investigation, T.M.; formal analysis, M.S., T.M.; investigation. All authors have read and agreed to the published version of the manuscript.

Funding: This work was supported by the National Science Centre Poland (grants number 2013/09/ B/NZ9/03169 and 2017/01/X/NZ9/00699); the Russian Ministry of Education and Science (grant number W 02.740.11.0325); the RFFR, Peat-AcroCato [grant number W 09-05-00235], and the Interact, Transnational Access (grant number WP4-FP7).

Conflicts of Interest: The authors declare no conflict of interest.

\section{References}

1. Osmond, D.L.; Gilliam, J.W.; Evans, R.O. Riparian buffers and controlled drainage to reduce agricultural nonpoint source pollution. Raleigh, North Carolina State University. N. C. Agric. Res. Serv. Tech. Bull. 2002, 318, 1-64.

2. Fabietti, G.; Biasioli, M.; Barberis, R.; Ajmone-Marsan, F. Soil contamination by organic and inorganic pollutants at the regional scale: The case of Piedmont, Italy. J. Soils Sediments 2010, 10, 290-300. [CrossRef]

3. Howard-Williams, C.; Downes, M.T. Nitrogen cycling in wetlands. In Nitrate, Patterns, and Management; Burt, T.P., Heathwaite, A.L., Trudgi, S.T., Eds.; John Wiley \& Sons: Chichester, UK, 1993; pp. 141-167.

4. Szajdak, L.; Maryganova, V.; Meysner, T.; Tychinskaja, L. Effect of shelterbelt on two kinds of soils on the transformation of organic matter. Environ. Int. 2002, 28, 383-392. [CrossRef]

5. Szajdak, L.; Życzyńska-Bałoniak, I.; Jaskulska, R. Impact of afforestation on the limitation of the spread of the pollution in groundwater and in soils. Pol. J. Environ. Stud. 2003, 12, 453-459.

6. Życzyńska-Bałoniak, I.; Szajdak, L.; Jaskulska, R. Impact of biogeochemical barrier on the migration of chemical compounds with the water of agricultural landscape. Pol. J. Environ. Stud. 2005, 14, 131-136.

7. Hill, A.R. Nitrate removal in stream riparian zones. J. Environ. Qual. 1996, 25, 743-755. [CrossRef]

8. Carpenter, S.R.; Caraco, N.F.; Correll, D.L.; Howarth, R.W.; Sharpley, A.N.; Smith, V.H. Nonpoint pollution of surface waters with phosphorus and nitrogen. Ecol. Appl. 1998, 8, 559. [CrossRef]

9. Finlay, J.C.; Small, G.E.; Sterner, R.W. Human influences on nitrogen removal in lakes. Science 2013, 342, 247-250. [CrossRef]

10. Wu, H.; Zhang, J.; Ngo, H.H.; Guo, W.; Liang, S. Evaluating the sustainability of free water surface flow constructed wetlands: Methane and nitrous oxide emissions. J. Clean. Prod. 2017, 147, 152-156. [CrossRef]

11. Kroeger, K.D.; Cole, M.L.; Valiela, I. Groundwater-transported dissolved organic nitrogen exports from coastal watersheds. Limnol. Oceanogr. 2006, 51, 2248-2261. [CrossRef]

12. Mueller, B.A.; Newton, K.; Holly, E.A.; Preston-Martin, S. Residential water source and the risk of childhood brain tumors. Environ. Health Perspect. 2001, 109, 551-556. [CrossRef] [PubMed]

13. Weyer, P.J.; Cerhan, J.R.; Kross, B.C.; Hallberg, G.R.; Kantamneni, J.; Breuer, G.; Jones, M.P.; Zheng, W.; Lynch, C.F. Municipal Drinking water nitrate level and cancer risk in older women: The Iowa women's health study. Epidemiology 2001, 12, 327-338. [CrossRef]

14. Fan, A.M. Nitrate and nitrite in drinking water: A toxicological review. In Encyclopedia of Environmental Health; Elsevier: Amsterdam, The Netherlands, 2011; pp. 137-145.

15. Ward, M.H.; Brender, J.D. Drinking water nitrate and health. In Encyclopedia of Environmental Health; Elsevier: Amsterdam, The Netherlands, 2011; pp. 167-178. [CrossRef]

16. Khaleel, R.; Reddy, K.; Overcash, M. Transport of potential pollutants in runoff water from land areas receiving animal wastes: A review. Water Res. 1980, 14, 421-436. [CrossRef] 
17. Overcash, M.R.; Davidson, J.M. (Eds.) Environmental Impact of Nonpoint Source Pollution; Science Publishers Inc.: Ann Arbor, MI, USA, 1980

18. Enfield, C.G.; Phan, T.; Walters, D.M. Kinetic model for phosphate transport and transformation in calcareous soils: II. Laboratory and field transport. Soil Sci. Soc. Am. J. 1981, 45, 1064-1070. [CrossRef]

19. Correll, D.L. Buffer zones and water quality protection: General principles. In Buffer Zones: Their Processes and Potential in Water Protection; Haycock, N., Burt, T., Goulding, K., Pinay, G., Eds.; Quest Environmental: Harpenden, Herdfordshire, UK, 1997; pp. 7-20.

20. Ryszkowski, L. Landscape Ecology in Agroecosystems Management; Ryszkowski, L., Ed.; CRC Press: Boca Raton, FL, USA, 2001; p. 384. [CrossRef]

21. Ilnicki, P.; Szajdak, L.W. Zanikanie Torfowisk (Peatland Disappearance); Wydawnictwo Poznańskiego Towarzystwa Przyjaciół Nauk: Poznań, Poland, 2016. (In Polish)

22. Krzywonos, K. Kształtowanie się czynników klimatycznych na zmeliorowanych torfowiskach, wpływających na warunki gospodarowania (The formation of climatic factors on drained peatlands affecting the management conditions). Bibl. Wiadomości IMUZ 1991, 77, 119-125. (In Polish)

23. Ryszkowski, L.; Kędziora, A. Modification of water flows and nitrogen fluxes by shelterbelts. Ecol. Eng. 2007, 29, 388-400. [CrossRef]

24. Szajdak, L.; Szczepański, M.; Bogacz, A. Impact of secondary transformation of peat-moorsh soils on the process of purification of ground water. Agron. Res. 2007, 5, 189-200.

25. Szajdak, L.W.; Życzyńska-Bałoniak, I. Effectiveness of a shelterbelt in decreasing the level of inorganic elements in agricultural landscape. Est. J. Ecol. 2013, 62, 24-34. [CrossRef]

26. Inisheva, L.I.; Szajdak, L.; Sergeeva, M.A. Dynamics of biochemical processes and redox conditions in geochemically linked landscapes of oligotrophic bogs. Eurasian Soil Sci. 2016, 49, 466-474. [CrossRef]

27. Hammer, D.A. Designing constructed wetlands systems to treat agricultural nonpoint source pollution. Ecol. Eng. 1992, 1, 49-82. [CrossRef]

28. Larson, A.C.; Gentry, L.E.; David, M.B.; Cooke, R.A.; Kovacic, D.A. The role of seepage in constructed wetlands receiving agricultural tile drainage. Ecol. Eng. 2000, 15, 91-104. [CrossRef]

29. Maynard, J.J. Spatial and Temporal Dynamics of Carbon and Nutrient Cycling in a Eutrophic Flow-Through Wetland. Ph.D. Thesis, University of California, Davis, CA, USA, 2009.

30. Hussain, I.; Raschid, L.; Hanjra, M.A.; Marikar, F.; van der Hoek, W. Wastewater Use in Agriculture: Review of Impacts and Methodological Issues in Valuing Impacts; Publisher: Colombo, Sri Lanka, 2002. [CrossRef]

31. Angelakis, A.; Snyder, S. Wastewater treatment and reuse: Past, present, and future. Water 2015, 7, 4887-4895. [CrossRef]

32. Recommendation No. $R$ (94) 6 of the Committee of Ministers to Member States for a Sustainable Development and Use of the Countryside with a Particular Focus on the Safeguarding of Wildlife and Landscapes (Adopted by the Committee of Ministers on 5 September 1994 at the 516th meeting of the Ministers' Deputies); Council of Europe Committee of Ministers: Strasbourg, France, 15 September 1999 ; No. R (99) 18; Available online: https:/ / www.refworld.org/docid/510101e02.html (accessed on 30 September 2021).

33. Ryszkowski, L.; Bartoszewicz, A. Impact of agricultural landscape structure on cycling of inorganic nutrients. In Ecology of Arable Land-Perspectives and Challenges; Clarholm, M., Bergstron, L., Eds.; Springer: Dordrecht, The Netherlands, 1989 ; pp. 241-246. [CrossRef]

34. Ryszkowski, L.; Bartoszewicz, A.; Kedziora, A. Management of matter fluxes by biogeochemical barriers at the agricultural landscape level. Landsc. Ecol. 1999, 14, 479-492. [CrossRef]

35. Szajdak, L.W. Shelterbelts: Efficient Element of the Landscape. Chemical and Biochemical Investigations of Ground Water and Soil; Szajdak, L.W., Ed.; LAP Lambert Academic Publishing: Saarbrücken, Germany, 2011; pp. 1-100.

36. Systematyka Gleb Polski (Polish Soil Classification). Rocz. Glebozn. 1989, 40, 1-150. (In Polish)

37. World Reference Base for Soil Resources 2014, Update 2015 (International Soil Classification System for Naming Soil and Creating Legends for Soil Maps; Food and Agriculture Organization of the United Nations, IUSS Working Group: Rome, Italy, 2015.

38. Szajdak, L.W.; Szczepański, M. Impact of the solvent on leaching organic matter from secondary transformation of peat-moorsh soils. In Physical, Chemical and Biological Processes in Soils; Szajdak, L.W., Karabanov, A.K., Eds.; Wydawnictwo Prodruk: Poznań, Poland, 2010; pp. 475-492.

39. Berg, B. Litter decomposition and organic matter turnover in northern forest soils. For. Ecol. Manag. 2000, 133, 13-22. [CrossRef]

40. Bernacki, Z. Differentiation of litter decomposition rates and nitrogen and phosphorous release in different types of tree stand. In Physical, Chemical and Biological Processes in Soils; Szajdak, L.W., Karabanov, A.K., Eds.; Wydawnictwo Prodruk: Poznań, Poland, 2010; pp. 183-196.

41. Licznar, M.; Drozd, J.; Licznar, S.E. Qualitative and quantitative composition of humic substances in deluvial soils of Płaskowyż Głubczycki. Zesz. Probl. Postępów Nauk Rol. 1993, 411, 139-148.

42. Sapek, A.; Sapek, B.; Gotkiewicz, J. Różnicowanie się składu chemicznego warstwy murszowej gleb torfowych (Differentiation of the chemical composition of the moorsch layer of peat soils). Wiadomości IMUZ 1991, 16, 109-131. (In Polish)

43. Chittleborough, D.; Smettem, K.; Cotsaris, E.; Leaney, F. Seasonal changes in pathways of dissolved organic carbon through a hillslope soil (Xeralf) with contrasting texture. Soil Res. 1992, 30, 465. [CrossRef] 
44. Burzyńska, I. Współzależność między zawartością DWO w roztworze ekstrakcyjnym $0.01 \mathrm{~mol} \mathrm{CaCl}_{2}$ a wybranymi składnikami mineralnymi w wodach gruntowych (The relationships between DOC content in the $0.01 \mathrm{M} \mathrm{CaCl}_{2}$ soil extract and macro- and microelements in ground waters). Woda-Środowisko-Obsz. Wiej. 2004, 4, 525-535. (In Polish)

45. Życzyńska-Bałoniak, I.; Ryszkowski, L.; Waack, A. Transport wodą gruntową rozpuszczonych związków organicznych poprzez zadrzewienia (Migration of dissolved organic compounds with groundwater through deciduous-tree shelterbelt). Zesz. Probl. Postępów Nauk Rol. 1998, 460, 167-176. (In Polish)

46. Meysner, T.; Maryganova, V.; Szajdak, L. Transformation of nitrogen compounds in the muckous soils of a forest island. Acta Agrophys. 2006, 7, 447-452.

47. Szajdak, L.W.; Szczepański, M. Impact of secondary transformation of peat-moorsh soils on the process of purification of ground water. In Mires and Peat; Klavinš, M., Ed.; University of Latvia Press: Riga, Latvia, 2010; pp. 125-142.

48. Reemtsma, T.; Bredow, A.; Gehring, M. The nature and kinetics of organic matter release from soil by salt solutions. Eur. J. Soil Sci. 1999, 50, 53-64. [CrossRef]

49. Ryszkowski, L. Protection of water quality against nitrate pollution in rural areas. In L'eau, de la Cellule au Paysage; Wicherek, S., Ed.; Publisher: Paris, France, 2000; pp. 171-183.

50. Hayden, M.J.; Ross, D.S. Denitrification as a nitrogen removal mechanism in a vermont peatland. J. Environ. Qual. 2005, 34, 2052-2061. [CrossRef] [PubMed]

51. De Klein, C.A.M.; Van Logtestijn, R.S.P. Denitrification in the top soil of managed grasslands in The Netherlands in relation to soil type and fertilizer level. Plant. Soil 1994, 163, 33-44. [CrossRef]

52. Barton, L.; McLay, C.D.A.; Schipper, L.A.; Smith, C.T. Annual denitrification rates in agricultural and forest soils: A review. Soil Res. 1999, 37, 1073. [CrossRef]

53. Luo, J.; Tillman, R.W.; White, R.E.; Ball, P.R. Variation in denitrification activity with soil depth under pasture. Soil Biol. Biochem. 1998, 30, 897-903. [CrossRef]

54. Jörgensen, R.G.; Richter, G.M. Composition of carbon fractions and potential denitrification in drained peat soils. J. Soil Sci. 1992, 43, 347-358. [CrossRef]

55. Smolander, A.; Kitunen, V. Soil microbial activities and characteristics of dissolved organic C and N in relation to tree species. Soil Biol. Biochem. 2002, 34, 651-660. [CrossRef]

56. Tiedje, J.M.; Sorensen, J.; Chang, Y.Y. Assimilatory and dissimilatory nitrate reduction: Perspectives and methodology for simultaneous measurement of several nitrogen cycle processes. In Terrestrial Nitrogen Cycles; Clark, F.E., Rosswall, T., Eds.; Ecology Bulletin 33: Stockholm, Sweden, 1981; pp. 331-342.

57. Smith, W.H. Character and significance of forest tree root exudates. Ecology 1976, 57, 324-331. [CrossRef]

58. Ryszkowski, L.; Marcinek, J.; Kędziora, A. Water Cycling and Biogeochemical Barriers in Agricultural Landscape; ZBŚRiL PAN: Poznań, Poland, 1990.

59. White, R.E. Principles and Practice of Soil Science: The Soil as a Natural Resource, 4th ed.; Wiley-Blackwell Publishing: Oxford, UK, 2006; p. 363. 